\title{
A QUESTÃO DA INCLUSÃO E A IMPORTÂNCIA DO DESENVOLVIMENTO DA CRIATIVIDADE
}

\author{
Gilton Luís Torres*
}

\begin{abstract}
Resumo: A inclusão tem sido tema recorrente e, ao mesmo tempo, preocupante para os profissionais da educação. Entendemos que a Arte pode ocupar um espaço significativo, por auxiliar no desenvolvimento dos alunos. Neste trabalho, tratamos, pois, de contextualizar a questão da criatividade em alunos com déficit intelectual como uma possibilidade produtiva à luz da Arte Terapia. Decorrem deste novo olhar, a análise do processo de individuação e dos conceitos junguianos que permitem o uso dos recursos arte terapêuticos a favor da compreensão do sujeito.

Tratamos das técnicas e dos fundamentos teóricos a elas inerentes que embasaram a seqüência de atividades aplicadas. Referimo-nos à pintura, colagem, teatralização $e$ bonecos que foram utilizados como alicerce teórico na elaboração do trabalho prático. A análise dos dados colhidos, em especial, a interpretação do processo criativo remete aos dados que se apresentam em três etapas: os avanços do grupo frente à aplicação da seqüência de atividades propostas e quanto ao processo criativo conquistado, os avanços individuais resultantes desta aplicação no que se refere à interação social, autonomia e organização e as intervenções analíticas da seqüência de atividades a favor da eficiência criativa. Destacamos as conquistas reconhecidas no processo criativo dos alunossujeitos a partir do trabalho proposto, com um destaque às intervenções bem sucedidas $e$ às reflexões significativas do trabalho planejado e aplicado.
\end{abstract}

Palavras-chave: ensino, inclusão, arte, criatividade.

\section{Introdução}

Muito se tem falado da questão da criatividade nos mais diversos âmbitos: no trabalho, na escola, em cargos gestores etc. A forma também como hoje se vê este tema - tão largamente explorado - nos motiva a pensar em como se dá o processo criativo.

Alguns indivíduos possuem uma característica em serem criativos, outros denotam uma certa carência criativa. Não nos parece ser determinante e fatalista a classificação "criativo" e "não criativo". Se pensarmos que o processo criativo pode ser construído, temos a chave que possibilitará a abertura de inúmeras portas para o conhecimento do "eu" e "do mundo"; do "eu" e "do outro"; em encontros que tendem a gerar infindáveis perspectivas, garantindo e/ou ampliando a capacidade criativa das pessoas.

\footnotetext{
* Professor efetivo das redes de ensino municipais de Jacareí e São José dos Campos. Pós-graduado em ArteTerapia. Integrante do grupo de apoio à inclusão na rede municipal de Jacareí.
} 
Imaginando que o homem, em sua longa caminhada até a modernidade, foi construindo a si próprio e o mundo, temos como pressuposto calcado na vertente junguiana, que quanto mais se desenvolvia a consciência do homem mais ele tornava-se capaz de evoluir. (BYINGTON, 1987). Desde os primórdios, o homem utiliza-se do fator interacional para compor seu mundo particular bem como de interar-se de fatores coletivos preponderantes à sua própria evolução e, conseqüentemente, à evolução da tribo, da família, da comunidade.

Isto posto, temos como certo que a natureza num primeiro momento ofereceu ao homem um aspecto organizacional e extremamente funcional que o auxiliou em sua busca por uma identidade e pela formação de seu "eu".

Segundo a psicologia analítica fundamentada por Jung (2000), o ego é considerado um produto da atividade criativa; formado por uma interação cultural, natural, genética e organizadora do desenvolvimento dos símbolos ${ }^{10}$ aliada aos diversos arquétipos ${ }^{11}$. Afirma-se que a formação do ego dá-se através de arquétipos já existentes e estruturados como, por exemplo, a vertente mítico-religiosa - fator determinante da identidade do "eu". Existem, portanto, características comuns às pessoas em todas as partes do mundo e isso é possível devido ao fato de existir uma consciência ${ }^{12}$ que é coletiva. Os indivíduos formam-se a partir de mesmas categorias arquetípicas construindo os substratos psíquicos que contribuirão, a posteriori, para seu processo de individuação ${ }^{13}$.

É fundamental, estar ciente das funções dos arquétipos encaminhando o desenvolvimento da criança para que esta possa equilibrar-se, vivendo em consonância com seus potenciais criativos. Considerando que a criança está a serviço de sua própria transformação, aliada a uma construção da personalidade (futuramente o processo de individuação) ela pode (e vai) conhecer mais intimamente quais fatores podem contribuir para uma relação mais harmoniosa conscienteinconsciente $^{14}$. (BYINGTON, 1987). É papel da escola, portanto, assegurar que deste contato com o consciente-inconsciente faça emergir materiais que servirão de suporte para vivenciar sua própria personalidade que num primeiro momento, é a da família; da tribo; da comunidade.

Dentro desta perspectiva, cabe salientar que o processo de interação com o meio e com o outro contribuem, sobremaneira, para a evolução dos alunos.

Neste estudo, com enfoque na teoria junguiana, olharemos mais cuidadosamente para os alunos com necessidades educativas especiais.

Dentro da diversidade existente no regime escolar, com ampla dimensão e de características diversas, os Parâmetros Curriculares Nacionais de Adaptações Curriculares (PCN, BRASIL, 1999, p. 23) destacam que a educação especial abrange:

crianças com condições físicas, intelectuais, emocionais e sensoriais diferenciadas;

crianças com deficiência e bem dotadas;

\footnotetext{
${ }^{10}$ Entende-se símbolo como a célula nobre ou a unidade da psique; sua função estruturante é coordenada por um arquétipo; reúne energia consciente e inconsciente e age como transformador, estruturando a consciência com o potencial arquétipo. (BYINGTON, 1987)

${ }^{11} \mathrm{O}$ arquétipo corresponde na psicologia, ao que o instinto significa para a fisiologia, o gen para a genética; o ângulo de cristalização para a minerologia e o padrão de comportamento para a zoologia. (BYINGTON, 1987). Trata-se, portanto, com o auxílio de Bueno (2001. p. 70), "de modelos de seres criados, de padrões exemplares", provenientes de um inconsciente coletivo.

${ }^{12}$ Refere-se a parte efetuadora central da estrutura da psíquica, na qual os símbolos atingem seu mais alto grau de discriminação. (BYINGTON, 1987)

${ }^{13}$ Neste processo o eu se torna capaz não só de se afirmar como também de considerar a posição do outro. (BYINGTON, 1987)

${ }^{14}$ Trata-se do material desconhecido do consciente; que pode ser revelado em nível consciente. (BYINTON, 1987)
} 
crianças trabalhadoras ou que vivem nas ruas;

crianças de populações distantes ou nômades;

crianças de minorias lingüísticas, étnicas ou culturais;

crianças de grupos desfavorecidos ou marginalizados.

Mais adiante, os PCN (op. cit, p. 24), fazem uma distinção quanto ao indivíduo com necessidades educativas especiais. Assim:

(...) por apresentar necessidades próprias e diferentes dos demais alunos no domínio das aprendizagens curriculares correspondentes à sua idade, requer recursos pedagógicos e metodologias educacionais específicas.

Neste trabalho, trataremos de indivíduos com déficit intelectual, ou seja, a deficiência mental que se caracteriza por:

Registrar um funcionamento intelectual geral significativamente abaixo da média, oriundo do processo de desenvolvimento, concomitante com limitações associadas a duas ou mais áreas da conduta adaptativa ou da capacidade do indivíduo em responder adequadamente às demandas da sociedade, nos seguintes aspectos: comunicação; cuidados pessoais; habilidades sociais; desempenho na família e comunidade; independência na locomoção; saúde e segurança; desempenho escolar; lazer e trabalho. (PCN, BRASIL, 1999, p. 24)

Entendemos, portanto, alunos com necessidades educativas especiais, todos aqueles indivíduos que apresentam algum déficit intelectual, afetivo, motor etc de ordem biológica/psíquica permanente ou não, resultando em perdas quanto à sua evolução psíquica, social e afetiva, abrindo, desta forma, um espaço/tempo não condizente entre idade cronológica e mental ou amadurecimento cognitivo.

Os sujeitos deste trabalho são crianças de uma instituição filantrópica da cidade de Jacareí/SP existente há 35 anos. A instituição criou-se a partir da necessidade de não haver na cidade um espaço dedicado às pessoas com necessidades educativas especiais. Desde então, seu trabalho foi crescendo e se aprimorando, expandindo em objetivos e ações. A escola de educação especial, segue os mesmos moldes do ensino fundamental da rede municipal de educação e a instituição ainda promove, dentro de si, um trabalho com relação aos adolescentes e adultos com necessidades educativas especiais objetivando, através de suas oficinas, em parceria com fábricas da região, a colocação destes indivíduos no mercado de trabalho.

Vale destacar, que são ainda crianças, adolescentes e adultos oriundos de nichos familiares fragmentados ou empobrecidos culturalmente, colaborando para que sua estagnação, enquanto indivíduo, seja suprimida ou não trabalhada. As privações às quais nos reportamos, são vistas pelo empobrecimento de suas produções e vivências, fazendo com que, uma vez mais, se pense que recursos artísticos expressivos venham colaborar tanto para a formação do "eu" como para o despertar de potencialidades. Desta forma, o professor/pesquisador autor deste trabalho, pretende elucidar como se dá o processo criativo dentro de oficinas artísticas com estes alunos que apresentam alguma dificuldade para expressar-se, para criar e se achar no mundo, construindo seu próprio caminho rumo a sua individualidade. 
Tais alunos tendem a ser, constantemente estimulados para que possam desenvolver suas potencialidades criativas em sala de aula. Não obstante, encontramos alunos com aptidões em diversas áreas de Artes, como por exemplo, a musical, a plástica e a cênica. Cabe ressaltar que, o contrário também se faz presente em alguns casos, ou seja, alguns alunos necessitam de ajuda para que seu potencial criativo possa ser despertado, fazendo com que canalizem suas energias para determinada área, culminando em maior aprendizagem, elaboração de conceitos e efetivação de atitudes.

Considera-se que, embora a natureza da psique possa comportar-se de forma imprevisível, a mesma reserva elementos onde o indivíduo possa desenvolver-se e diferenciar-se dos padrões coletivos de comportamento, sentimentos e atitudes. Neste enfoque, aproveitaremonos de recursos artístico-terapêuticos para que os alunos possam empreender uma formação de personalidade bem aproveitada que não só os diferencie do padrão coletivo, mas que, em primeira instância, possa propiciar o seu mais alto potencial frente a sua existência. (BYINGTON, 1987).

Nos propomos, então, a investigar, a partir da aplicação de uma sequiência de atividades, o processo criativo resultante, da mesma, em alunos com necessidades educativas especiais; juntamente com a limitação criativa imposta pelo déficit acarretado pela Deficiência Mental, acompanhado ou não de psicopatias.

Isto posto, tentaremos responder às seguintes questões:

- Como as técnicas e vivências em Arte-Terapia podem ser co-partícipes no processo de desenvolvimento criativo do aluno?

- Quais avanços (com relação à interação social, autonomia, organização) podem ser reconhecidos como fruto do processo de aplicação de uma seqüência de atividades em Artes?

No estudo cuidadoso deste processo, quais pontos estruturantes podem sinalizar necessidades de investimento maior, quando se tem em vista a busca de avanços no potencial criativo?

Baseado na psicologia junguiana e seus estudos com relação aos processos criativos, individuação e arquétipos; buscaremos trilhar um caminho muito próximo ao proposto pela teoria em oficinas de criatividade, para que se possa desta forma, observar o desenvolvimento dos diversos alunos envolvidos no processo.

As oficinas de criatividade supracitadas consistem em propostas de trabalho envolvendo a plástica ou outro recurso artístico aliado a técnicas de relaxamento; contos de fada e reconto, montagem coletiva e individual de painéis que retratem a idéia firmada de maneira concreta. Mais que observar o processo, torna-se imperativo o registro, do mesmo, numa perspectiva onde seja possível captar a linha de conduta do autor (es) da obra, os materiais utilizados; sua relação com o grupo e sua relação com o objeto em construção. Outros pontos são passíveis de serem lidos, como por exemplo, a autonomia na busca de recursos e materiais que melhor expressem sua visão plástica do objeto a ser construído. A autonomia é um dos fatores que merece atenção especial dentro destas oficinas, pois revelarão se o indivíduo - dentro do processo de elaboração plástica - consegue decidir e escolher quais materiais pretende usar, em que ordem os disponibiliza para manuseio e ainda, se necessita ou não de interferência direta do professor ou do grupo para a finalização de seu trabalho.

Os sujeitos deste trabalho são alunos com idade escolar de sete a doze anos e idade mental variando de três a nove anos; segundo avaliações com os testes da Columbia ${ }^{15}$, Raven ${ }^{16} \mathrm{e}$ H.T.P. ${ }^{17}$

\footnotetext{
${ }^{15}$ COLUMBIA-CMMS (Escala de Maturidade Mental Columbia) Harcout Brace e World, Inc. New York.
} 
Muito mais como entender seu processo criativo e sua autonomia frente ao trabalho finalizado, as oficinas buscarão o desvelar destas produções plásticas. Haverá, portanto, um momento em que tais alunos explicitarão suas idéias acerca daquilo que produziram: quais elementos são significativos em sua obra e por quê. A leitura destas obras não acontecerá de forma unilateral. $\mathrm{O}$ autor, em primeira instância, a abordará de tal forma que o interlocutor possa inferir, na mesma. A leitura de ambos - autor e interlocutor - buscará caracterizar quais avanços este aluno fará no percurso de seu desenvolvimento criativo e quais elementos estruturantes precisam de melhores cuidados e de trabalho mais sistematizado. Aqui, entendemos, como elementos estruturantes, fatores motivacionais que o impulsionem na busca entusiasta pela formulação e construção plástica de suas idéias. Para efeito organizacional e didático, faremos alguns encontros que irão caracterizar, desta forma, as oficinas de criatividade. Neles, iremos dispor das seguintes etapas:

- proposta de um tema ao grupo;

- levantamento de material necessário;

- organização do espaço utilizado;

- realização do trabalho em si;

- avaliação individual e coletiva realizada, pelo grupo frente às suas produções, com interferência mínima do professor/pesquisador.

Sendo assim, o trabalho segue as seguintes etapas processuais:

- Quanto à seleção dos sujeitos:

Dez (10) alunos de uma mesma sala com necessidades educativas especiais com idade mental variando de três (3) a nove (9) anos e idade escolar entre sete (7) e doze (12) anos.

Elaboração da seqüência de atividades com base na fundamentação teórica explorada;

- Quanto à coleta de dados:

Aplicação das oficinas de criatividade e registro sistemáticos dos dados quanto ao processo criativo grupal e aos avanços individuais frente à interação social, autonomia e organização;

- Quanto à análise dos dados:

Leitura vertical dos registros elaborados durante a aplicação da seqüência de atividades e análise dos dados, tendo em vista os dois focos de análise supracitados- grupal e individual;

Leitura horizontal/comparativa dos avanços grupais e individuais e análise dos dados, revelando pontos em comum encontrados no processo;

Análise das possíveis intervenções do professor/pesquisador, ou seja, pontos estruturantes que sinalizam necessidades de um investimento maior e valorativo do potencial criativo a partir dos dados anteriores.

No que diz respeito à fundamentação teórica do trabalho, alicerçamo-nos nos pressupostos de Jung (2000) em conciliação com os princípios da Arte Terapia apoiados em Pain; Jarreau (2001). As análises de Byington (1987) muito contribuíram para o entendimento do desenvolvimento da personalidade respaldados nos conceitos junguianos, enquanto Ostrower ( 1977) revela-nos a preocupação com o potencial criativo e em como o processo de criação do homem pode ser desenvolvido além de sua existência individual- consciente ou não.

\footnotetext{
${ }^{16}$ Manual de Matrizes Progressivas Coloridas, de Raven J.C. - Escala Especial.

${ }^{17}$ The House - Tree Person (H.T.P.), In Buck, J.N.
} 


\section{A arte terapia a serviço da construção do processo criativo}

Os alunos com necessidades educativas especiais carecem de maior estímulo para realizar suas produções; quer sejam elas plásticas, montagem de texto oral, recortes e colagem etc. Isto porque, geralmente, além do déficit acarretado pela deficiência mental, existe a problemática da família (super proteção/descaso) onde o meio termo parece inexistir; a instituição em si, atravancando burocraticamente a vida dos indivíduos e o aspecto social; em que o preconceito e o desconhecimento ainda falam mais altos.

Diante dessa perspectiva quase caótica, buscamos recursos artísticos terapêuticos na tentativa de maximizar o potencial criativo destes indivíduos dentro da instituição. Desta forma, tentaremos devolver ou resgatar, a cidadania outrora esquecida ou posta de lado - quer seja pela família, quer seja pelo próprio fator social em questão.

Não é o caso de tratar o deficiente como diferente, mas assegurar e legitimar sua cidadania fixada muito claramente em artigos e leis. Oportunizar é muito mais que oferecer condições, é de fato garantir espaço de criação, de trabalho, lazer e saúde a estes indivíduos. Motivamo-nos em assim pensar porque muito se tem discutido a respeito da criatividade, e em como ela pode ser entendida, elaborada e desenvolvida. Certamente, isto cabe a todo indivíduo que tenha, assegurado, pelos órgãos competentes, família e escola, o mínimo de eqüidade social.

Pensando em recursos artísticos expressivos, coloca-se o indivíduo num ponto de vista onde a subjetividade pode ser explicitada de maneira leve e descontraída, ajudando-o a se entender e fazer-se entender. Não obstante, - o trabalho artístico - oferece um prazer bastante positivo ao indivíduo/autor de sua obra, suscitando seu lugar no espaço, o espaço social outrora negado.

Alguns problemas podem ser de origem orgânica, entendendo-se desta forma qualquer alteração (permanente ou não) nos mecanismos de regulação do organismo; outros porém podem ter derivações genéticas ou psíquicas. (PAÏN; JARREAU, 2001).

Alguns indivíduos requerem mais atenção para procurar entender quem são - precisam de ajuda para localizar-se no espaço social ao qual estão inseridos e mais ainda necessitam de auxílio para descobrir-se enquanto "uno", "único".

Para este processo, de confrontar-se com o "eu" e reconhecer-se como ser capaz, é necessário não só uma ressonância afetiva entre o meio que circunda - família/escola- mas também de um suporte que o ajude a construir esta imagem do "eu", bastante danificada ou esquecida por ele próprio, pela família, escola e sociedade.

Salientamos desta forma, que o indivíduo com necessidades educativas especiais, carece de ajuda para confrontar-se com sua própria imagem, resgatando-a e estruturando-a, culminando num processo de transformação que o coloque não numa posição de "igual" ou de "diferente", mas numa posição onde o que prevaleça seja a igualdade de oportunidades e o respeito frente à diversidade.Assim: "o homem é este ser que se faz imagem; o homem é este ser que se faz das imagens; o homem é este ser que faz as imagens" (CAPELIER, 1980 apud PAÏN; JARREAU, 2001, p.10).

Entendendo melhor este aspecto tridimensional de homem, podemos concluir que nos apropriamos de imagens que nos revelam coisas, que contribuem para nos tornarmos melhores em alguns aspectos; podemos ainda considerar que somos uma representatividade única com direito a espaço e lugar no mundo (seja este o núcleo familiar/escolar/religioso/social etc); e por fim, podemos entender que cada ser independente de seu déficit intelectual, pode contribuir no fazer o mundo e seus espaços, dando mais colorido e vida, sons e cores. Imprime desta forma 
sua "impressão única" necessária às diferentes partes que formam o todo. Cada um tem, necessariamente uma contribuição à dar. A nossa, enquanto seres que ajudam nesta busca do "eu", é a de achar o caminho por onde toda vazão criativa possa ser frutificada, revelando talentos ou simplesmente garantindo que a igualdade de oportunidades não foi negada.

Divisando um processo histórico de criação, podemos apontar o início remoto da civilização quando o homem começa a produzir seus objetos com necessidades específicas e fins de subsistência. Então, os objetos constituídos neste período tornam-se os instrumentos pelos quais obter alimento é imperativo. Com o passar dos tempos, são fixadas a residência, a domesticação de animais e a agricultura. Desta forma, a tendência natural do homem é construir objetos outros que além de preparar alimentos poderão ocupar lugar decorativo e sagrado em suas vidas.

Segundo Païn; Jarreau (2001, p.11), “(...) o homem acrescentou à fabricação dos objetos um excedente não-funcional ligado à decoração (...) marcado na sua individualidade e na unicidade".

Não queremos propor tão pouco a objetivação estética dos trabalhos realizados pelos diversos indivíduos nas oficinas (isto pode ocorrer de forma espontânea), porém trata-se também de possuir elementos que suscitem motivação criadora frente a dado objeto. Tal estímulo vem ao encontro de um desejo de criar algo e neste algo, poder se identificar como autor e mais ainda, obter satisfação e prazer sobre aquilo que se produziu. Desta forma entende-se que "cada sujeito constrói um sistema de referências estáticas com interdições e regras que são adquiridas através do seu grupo de pertencimento" (PAÏN; JARREAU, 2001, p.12).

Seguindo esse caminho, pode-se entender que a atividade plástica pode conferir ao autor um caminho não verbal de comunicação com o outro e com o meio ao qual está inserido. Este momento pode ser marcado como aquele em que o indivíduo expõe seus sentimentos ora depositados no realizar da produção e criação artísticas.

Esclarece-se desta forma o processo de individuação pelo qual todos estamos sujeitos a trilhar e um pouco mais que isto, entendemos que a unicidade criadora reveste-se das interferências sofridas pelo grupo ao qual pertence o sujeito que produz. Esta busca, portanto, comporta momentos distintos que merecem atenção especial por parte do profissional arteterapeuta que acompanha um grupo de indivíduos.

Num grupo específico de trabalho artístico-terapêutico, o que buscamos é o desenvolvimento da capacidade de, o indivíduo frente à evolução de seus trabalhos, desenvolver maior autonomia diante das diversas facetas das exteriorizações e criações de suas imagens. Cabe desta forma explicitar se esta autonomia conseguida através de recursos expressivos será transferida para outras áreas de sua vida como o vestir-se e pentear-se sozinho por exemplo.

Uma vez mais coloca-se que o trabalho está centrado no sujeito com déficit intelectual e sua busca por um universo de imagens que, além de significativas, possam trazer à tona conflitos subjetivos. Pretende-se desta forma, construir um caminho que leve à superação de tais conflitos ou pelo menos o amenizar de conflitos.

Pontuado por Païn; Jarreau (2001, p.16),

deve-se constituir o profissional arte-terapeuta de recursos bastante claros de exploração artística bem como domínio de técnicas que garantam o desvelar do sujeito que produz imagens e das imagens que revelam o sujeito, numa relação dialética onde seja imperativo ajudá-lo em sua busca pelo "eu". 
O domínio das técnicas pressupõe um espaço apropriado, material diversificado, onde impressões de estilo pessoais serão construídas. Entendemos desta forma que a existência de recursos-artísticos combinam com a apresentação de materiais; preparação do local e a escolha de um recurso eficaz a ser utilizado.

Este espaço tende a ser o mais agradável possível e um lugar onde se possa entrar em contato com sentimentos profundos a serem trabalhados. Organizar-se portanto e organizar o mundo, pressupõe segundo Eliade (2001, p.36) que "não se pode viver sem uma abertura para o transcendente; em outras palavras, não se pode viver no Caos".

A escolha de um espaço portanto, carrega em si a tenacidade de habitá-lo e organizá-lo mantendo desta forma uma relação com o mundo mais que existencial - dialética.

A relação transcendente que aqui se coloca, faz projetar o homem como produto do mundo divinizado e do mundo profano (entendendo profano como a religioso). Estabelece-se uma relação dual onde o primordial no processo de encontrar-se, situa-se em fixar-se em imagens que tornaram-se reflexos de todo processo vivido pelo sujeito em questão, e que busca a priori, consciente ou não, seu lugar no mundo. Situar-se e organizar-se portanto, requer correlacionar-se com o mundo circundante.

Para Jung (2000, p.165), "a meta do processo de individuação é a síntese do si mesmo". $\mathrm{O}$ indivíduo tem portanto, a condição de correlacionar aspectos opostos consciente/inconsciente buscando uma função mediadora que abarque em si transformações que promovam a expansão de sua consciência e ainda: - promover em caráter de antecipação a mediação. Desta forma, o indivíduo deixa de possuir aspectos plurais em sua personalidade (da família, da tribo etc) para recair numa busca do "eu", enquadrando-se em sua própria síntese de personalidade.

\section{Ser aquilo que se é ou o processo de individuação}

O termo "individuação," segundo Jung, é usado "no sentido do processo que gera um individuum psicológico, ou seja, uma unidade indivisível, um todo".(JUNG, 2000, p.269).

$\mathrm{O}$ aspecto inconsciente da psique não é de conhecimento do consciente, portanto, deve o indivíduo buscar materiais que lhe são revelados através de desenhos, sonhos etc, para correlacioná-los com sua vida prática e, desta forma, gerar um processo que garanta a sua individualidade. Muitas vezes, ou na maioria das vezes, este processo torna-se muito denso para ser mediado pelo indivíduo que busca equilibrar-se, mesmo porque aspectos inconscientes desconhecidos do "eu", da consciência podem também ser negados por ele.

O mergulhar em si mesmo não garante o reconhecimento e aceitação daquilo que se é. Em contrapartida, a investigação cuidadosa dos fenômenos da personalidade, merecem processos onde se possa mensurar materiais comprovantes, pertinentes àquilo que de fato faz parte do indivíduo. Não se trata porém de induzir a isto ou aquilo, mas compreender-se, por etapas investigativas, os fenômenos psíquicos.

Sob esta ótica, Jung (2000, p.270), coloca que

(...) tornou-se insustentável supor um eu que expressasse a totalidade psíquica. Pelo contrário, tornou-se evidente que o todo deve necessariamente incluir tanto o campo 
imprevisível dos acontecimentos inconscientes, como a consciência, o eu só podendo ser o centro da consciência.

Aludindo mais uma vez a Jung (op.cit p.270), pode-se afirmar que "nada que o espírito humano produz está fora do ambiente psíquico". Percebemos desta forma, o aspecto dual e dialético do formar-se que está presente antes mesmo da ação. O inconsciente não é uma tal forma vazia. Carrega elementos que podem expressar-se de maneira surpreendente, caracterizando assim, que ele (inconsciente) é uma realidade.

Assim, algumas coisas - principalmente as que se referem à afetividade - podem aparecer hoje ou daqui a muitos anos. Isso denota, enquanto realidade do inconsciente que estes elementos sempre existiram na natureza da psique e que num dado momento ganham forma, relevância e significação. Tomando o inconsciente como um traço de memória - futura ou passada - redescobrimos coisas, ações, funções e sentimentos pertinentes a uma ancestralidade fruto próprio daquilo que somos.

Contrariamente ao que pensamos do inconsciente - "um nada" - somos surpreendidos pela sua realidade, pois toda ação do indivíduo já estava nele antes de realizá-la. Embora a natureza da psique seja difícil de ser compreendida, (JUNG, 2000, p.272) observa que "qualquer fato mais cedo ou mais tarde será de conhecimento da consciência"; este revelado, oferece a oportunidade da compreensão do sujeito por ele mesmo e por quem o ajuda em seu desvelar e, apesar de nos parecer um ato conturbado, este processo ocorre de forma bastante natural.

Cabe salientar que somente a consciência possui um centro - "o eu". O inconsciente é, portanto, desprovido de um centro, de um eu. O eu evoca a consciência de maneira que pensamos, sentimos, existimos. Por outro lado, é sabido, através dos trabalhos de Jung, que o inconsciente possui características próprias tidas por ele, como sendo o nome do processo investigativo ao qual se ateve, garantindo talvez maior praticidade e adequação quanto ao uso destas terminologias.

Desta forma, constata que "no inconsciente de cada homem está oculta uma personalidade feminina e há uma personalidade masculina oculta em cada mulher" (JUNG, 2000, p.277). Conclui-se desta forma que possuímos elementos contrários de nossa forma sexual real. Isto não quer dizer porém, que tenhamos consciência desta característica da psique. Parafraseando Jung, tais figurações ocorrem em sonhos, onde é possível observar as conotações e ações da figura da anima, ${ }^{18}$ por exemplo. Constatando mais uma vez que o inconsciente não é "um nada", Jung nos revela outra figura do inconsciente - a sombra - que de maneira sintética refere-se a personificação de tudo o que o indivíduo rejeita em si por importuná-lo, por não ser passível de aceitação em nível consciente. Em se tratando do aspecto de inconsciente pessoal, figura em projeções sobre pessoas no campo dos sonhos.

Segundo Byington (1987, p.7), o processo de individuação pode ser interpretado como: "a necessidade de uma diferenciação do coletivo, uma transformação arquetípica da personalidade que, se bem aproveitada, leva o indivíduo a se diferenciar dos papéis sociais e a atingir a plenitude do seu potencial existencial".

Figura, portanto, que o processo de individuação é algo construído, um confrontar-se com si mesmo, uma revolução psíquica e social culminando com o vir a ser. Não obstante, tal processo não se esgota, pois o ser humano é dotado de uma capacidade infinita de criação e

\footnotetext{
${ }^{18}$ Forma feminina inconsciente presente no inconsciente de todo homem. (JUNG, 2000, p.277).
} 
transformação. Logo que chega a um patamar, alça vôo para um novo encontro consigo, ampliando-se numa espiral sem fim.

\section{Técnicas de arte terapia a favor da compreensão do sujeito}

Neste item, abordamos algumas técnicas que contribuem sobremaneira para a compreensão do sujeito. O fazer artístico expressivo, proporciona ao sujeito autor de sua obra, um dialogar entre o consciente - inconsciente de tal forma que isso possibilite que materiais inconscientes possam emergir (tornar-se consciente) propiciando, a partir destes elementos, a sua compreensão. Assim, conseguirá enxergar caminhos por onde toda criatividade, sentimentos e emoções circulam e como acontecem. Elas portanto (as técnicas) podem ser uma forma de ordenação interna explicitado pelo fazer artístico que, conduz necessariamente a um descobrirse, através de um caminho agradável, lúdico e ainda; de tal forma subjetivo, que libere todos seus desejos que o falar por si só não seja capaz de exprimir. A exteriorização dos sentimentos acontece de forma mais amena - não menos importante - e com certeza de maneira forte e altamente pontual. Assim, em nossas oficinas, fizemos uso da pintura e da colagem além da confecção dos bonecos. Mais do que liberar emoções e sentimentos, estas técnicas dentro das oficinas, ofereceram também muito material para o diálogo. Foi possível, portanto, esclarecermos muitos pontos com relação ao grupo e individualmente a partir dos recursos expressivos.

As técnicas foram co-partícipes do processo de criação dentro das oficinas. Foi com elas e por elas que os indivíduos puderam se colocar no grupo, puderam alçar vôo na pele de outros personagens, puderam sonhar e criar. Entendemos desta forma as técnicas como um canal aberto entre os indivíduos e o professor-pesquisador e também como a expulsão dos sentimentos e emoções que circulavam por todo o espaço reservado a estes momentos mágicos vividos em grupo e individualmente.

\section{- A PINTURA}

“(...) Partindo da necessidade de deixar uma marca, de apropriar-se de um objeto, de fazê-lo seu "duplo", o homem, no curso de sua história, nunca cessou de pintar". (PAÏN; JARREAU, 2001, p.77). É exatamente essa necessidade de deixar uma marca, de se apropriar de dado objeto que nos leva a oferecer a técnica de pintura aos diversos indivíduos de um grupo. Deste modo, este caminhar contribui para a construção de um novo desvelar, resultando talvez, do fazer artístico a obra de arte.

Diversos podem ser os materiais e suportes para o realizar da pintura. $\mathrm{O}$ mais importante deste processo é poder expressar-se.

As cores ajudam-nos a descobrir um novo mundo que enquanto descoberto emite ressonâncias de um mundo pessoal, intimista. A palheta de cores portanto, é algo que pode ser experimentado pelo indivíduo que entra em contato com a pintura bem como os limites escolhidos perfazendo uma definição de estilo a posteriori.

Recobrando a busca de cores, limites e estilos nas mais diferentes épocas, vale dizer que a pintura estabelece-se por questão de escolha pessoal com interferências de estilo dentro de um 
determinado contexto ou época. Assim sendo, a pintura tende a possuir ritmo, composição, movimento etc.

"As cores têm uma beleza própria que devemos preservar, tal como tentamos preservar o som da música. É uma questão de organização, de encontrar a construção em que a cor conserva beleza e frescura". (MATISSE, 2001, p.44)

A pintura, portanto, propicia o aprimoramento da técnica para que seu autor possa de fato estabelecer um processo criativo diante daquilo que produz, satisfazendo-o enquanto autor que se faz também na obra que produz.

A cor e a forma daquilo que se constrói, têm significados distintos e merecem olhares particulares. A cor diz muito de nossos sentimentos e sensações enquanto a forma está diretamente ligada com o movimento. (PAÏN; JARREAU, 2001).

O pintar oferece ao pintor a possibilidade de experimentar os movimentos que deseja inserir como marcas em sua obra através das formas, para depois completá-las com as cores que vem ao encontro das formas que desenhou revelando não só uma preferência ou estilo - revela também emoções e sentimentos.

Isto fica claro quando Van Gogh, $(2004$, p.46), fala sobre seu quadro "O Café de noite na Place Lamartine":

No meu quadro do Café de Noite, tentei expressar que o Café é um lugar onde alguém pode se arruinar, enlouquecer ou cometer um crime. Pelos contrastes das tonalidades de um rosa delicado e vermelho-sangue e vermelho-escuro, de um verde suave Luís XV e um verde veronês contra um amarelo-esverdeado forte - tudo isto numa atmosfera de rubro de fogo infernal e um amarelo baço de enxofre - quis exprimir o poder tenebroso de uma taberna.

A fala de Van Gogh (op. cit, p.46) deixa muito clara, a delimitação do espaço pelas formas de seu quadro bem como os fortes sentimentos ali expostos através das cores que usou para pintá-lo contrapondo fusões e matizes.

Cremos assim, que as cores, participam do processo de construção e representação psicológica de todos nós, refletida nos mais diversos comportamentos, culturas e épocas.

Destacando a impressão de um código pessoal de cores, Païn e Jarreau (2001, p.103), colocam que:

Em um processo terapêutico, o que nos interessa é a reconstrução do código subjetivo das cores, isto é, descobrir quais são, em razão da insistência de sua presença ou da obstinação de sua falta, os tons mais importantes para o sujeito, assim como aqueles que são capazes de comovê-lo e de promover nele ressonâncias e associações com experiências vividas.

O problema maior, portanto, é, junto com o indivíduo que pinta, procurar a significação das cores escolhidas. $\mathrm{O}$ que nos trazem de informações, o que querem representar e quais mensagens estão implicitamente sendo depositadas sobre o suporte escolhido. A originalidade e a mensagem pictórica são, assim, o cerne de uma linguagem análoga a serem entendidas, reelaboradas num perfazer concomitante da obra e do artista. 


\section{A COLAGEM}

As atividades com colagens, assim como ouso de qualquer outra técnica, pressupõe uma escala de atividades em ascensão. Assim, parte-se de uma atividade menos elaborada para uma mais elaborada, contendo maiores graus de dificuldade e/ou elaboração por parte do indivíduo que a executa.

São Païn; Jarreau (2001, p.181) que destacam:"essa técnica, muito rica, ganha valor psicopedagógico, se é proposta com graduação nas dificuldades." Neste contexto, as autoras exprimem então, que as crianças e adultos ao fazerem uso desta atividade podem primeiramente rasgar o papel com as mãos antes de cortá-los com a tesoura favorecendo assim um contato sensorial direto com o material a ser manipulado.

Dando maior entendimento quanto a seqüencialidade que a técnica oferece, o que foi rasgado ou cortado, pode ser agora colados sobre um suporte. Os materiais não se reduzem apenas aos papéis cortados. A diversidade de materiais disponibilizam-se em tecidos, couro, lã, pequenas peças metálicas (arruelas, porcas etc), miçangas, botões... O trabalho com colagens permite ao indivíduo comparar suas pinturas e desenhos com a montagem do recortar e colar justaposto a outros materiais. Assim: "Na pintura, a superfície cria-se dela mesma sem que a criança repare. Ela está ligada a espessura do pincel, enquanto um desenho à lápis, deve-se dobrar o traço para que ele se torne superfície.” (PAÏN; JARREAU, 2001, p.182).

Pensando numa sucessão de atividades que levem a elaboração e domínio da técnica, as autoras ainda destacam: "pouco a pouco, a criança passa da etapa da ruptura compulsiva do papel, em um só gesto, à sucessão dos pequenos gestos que lhe permitem obter uma forma que ela antecipou".

Propondo então uma estruturação gradativa de trabalhos, os indivíduos desenvolvem a condição primeira de antecipar seu trabalho - pensar sobre ele e de tal forma que possa realizar a classificação e escolha de materiais, textura, cores e matizes.

Importante também salientar a importância dos papéis ditos neutros:

(...) marmorizados, rajados, com bolinhas etc, sem nenhuma imagem interpelante. Caracteriza-se assim, uma posição contra a tendência bastante generalizada de deixar-se fascinar pela imagem sem conseguir recuperar eficazmente o papel em um contexto plástico - enquanto colorido ou material. (PAÏN; JARREAU, 2001, p.183).

A atividade de colagem não cessa em si. Quando pronta, podemos sugerir, segundo as autoras o realizar da paisagem que complementa a colagem, um céu, animais etc. A atividade de colagem propicia a caráter da antecipação, suscitando assim quais sobreposições legitimam a imagem produzida e quais não, favorecendo a organização e a didática do trabalho em si.

Findando o uso desta técnica - sem a perda de sua dimensão simbólica e significação, vemos que:

De um ponto de vista mental, a colagem é uma atividade de análise e síntese, não somente uma função lógica, mas semelhante ao tipo do processo que se realiza na linguagem, transformando as palavras em letras e em sílabas cujo sentido desaparece no 
momento onde se encontram uma posição em uma nova composição, com um outro sentido. (PAÏN; JARREAU, 2001, p.190).

Trata-se, portanto, de um uso de técnica pedagógico e terapêutico, propiciando a compreensão do espaço-motor onde o objetivo maior é "reproduzindo de uma maneira metafórica as transformações de aventura de significar (de ser significante)". (PAÏN; JARREAU, p.2001, p.190).

\section{A TEATRALIZAÇÃO E OS BONECOS}

Parafraseando as autoras (op. cit) a teatralização e os bonecos permitem, principalmente às crianças, a possibilidade de inúmeras explorações acerca daquilo que se produz - poder voar na capa do herói, ser o vilão da história, a criação plástica dos bonecos, a criação de cenários, a aplicação de acessórios etc.

Estas duas funções concebem aplicações artístico-terapêuticas aos membros do grupo. A intenção de conferir aos diversos personagens uma impressão peculiar, fazendo emergir a comunicação necessária com o arteterapeuta, facilitando a compreensão de seu mundo de idéias e de como se processam. Assim, podemos pensar numa história que possibilite o jogo dramático, alterado pelo grupo se assim for necessário.

Com relação à escolha da história, as autoras entendem que:

(...) o texto escolhido comporta elementos de diálogo que servem para provocá-la. A trama da história deve ser curta, concisa, linear e comportar ações e situações que se repetem de uma maneira rítmica. Quando do jogo dramático, o ritmo, semelhante àqueles das historinhas cantadas, quando suficientemente colocado em evidência pelo contista, torna-se fonte de prazer para as crianças. (PAÏN; JARREAU, 2001, p.137).

No tocante a representação, as autoras (op. cit) pontuam que devem ser observadas as seguintes fases:

a adequação da voz;

a capacidade de simular os sentimentos pela expressão dos comportamentos quanto pela verbalização;

as atitudes racionais;

a capacidade de suportar as frustrações;

o vivido dos conflitos;

a capacidade argumentativa.

Constroem-se então, mundos distintos onde real e imaginário podem se fundir em combinações que, a posteriori, garantam a compreensão do sujeito no caminho que segue rumo ao seu descobrir-se.

Com relação à apresentação de seus bonecos/personagens, os membros do grupo têm a possibilidade de a eles atribuir sentimentos, funções, sexo etc. Assim, as autoras (op. cit) colocam que devem ser observadas as dificuldades de se investir neste "personagem-espelho", 
uma vez que tais sentimentos, funções ou emoções trazem à tona elementos do "eu" em construção. Merecem, portanto, cuidados quanto à aceitação daquilo com o que se defronta (as frustrações, as angústias) e modificações necessárias para a adequação que possibilitará ordenação interna suficiente para o harmonizar-se.

\section{4- Interpretando o processo criativo}

Tendo em vista os objetivos dos trabalhos e as etapas procedimentais anteriormente citadas (cf. p.6 da Introdução), os procedimentos de análise são os seguintes.

Inicialmente, contextualizamos ao leitor, a seqüência proposta composta de cinco atividades aplicadas uma vez por semana no espaço de sala de aula e anexos. Ao evidenciarmos as atividades, tratamos dos avanços gerais constatados diante de cada proposta que nos permite uma análise do processo criativo. (cf. proposto no objetivo A) A análise dos avanços gerais se faz pela confirmação presente em alguns casos. Toda vez que foi necessário referenciá-los e/ou exemplifica-los como confirmação de resultados mais amplos adotou-se a nomenclatura "ALUNO", acompanhado de um número que se seguirá até dez em ordem crescente. Deste modo teremos então: ALUNO 1 (A1), ALUNO 2 (A2), ALUNO 3 (A3)... ALUNO 10 (A 10).

Em seguida, com objetivo de analisarmos os resultados/avanços individuais frente à interação social, autonomia e organização nossa análise focaliza aluno por aluno e complementa o objetivo A supracitado. Ainda para efeito organizacional, não analisaremos os efeitos de crescimento individual em grau comparativo, mas sim como ganho pessoal, único, uma vez que cada indivíduo possui um ritmo próprio para a elaboração e execução das atividades. Assim, a comparação dar-se-á do indivíduo para com ele mesmo, de tal forma que possamos mensurar seu crescimento dentro do desenvolvimento das oficinas, bem como ganhos que refletem, a posteriori, mudanças significativas.

A teatralização da história pelo grupo, parte de uma consigna simples. Dividir os papéis e dizer suas falas. Aqui cada elemento do grupo tem necessariamente seu lugar neste universo mágico do faz de conta, que é em contrapartida, achar seu próprio lugar na família e na escola.

Desta forma, segundo as autoras o primeiro momento serve para testar a capacidade de se defrontar com todas as tarefas ao longo das oficinas e, a posteriori, relacionar-se com os mecanismos de identificação e de projeção. (PAÏN; JARREAU, 2001, p.65).

Mesmo o fato de não conseguir se expressar, de estar estática na frente do grupo, representa ainda através do olhar e do sorriso meio sem graça o desejo de pronunciar-se, o desejo de colocar-se diante do grupo, o desejo de que se pode contribuir com o grupo. Parafraseando as autoras, este momento pode significar

(...) uma página em branco", uma angústia pela busca daquilo que ainda está sendo construído, um tempo maior para o material desejoso de sair e brotar, pelo gesto e pela fala. "É preciso passar por essa angústia sem ser absorvido por ela. (PAÏN; JARREAU, 2001 p.65).

Isto nos faz pensar, em que tipo de ajuda pode-se oferecer a esta criança que busca dar vazão as suas significações de mundo através do personagem que representa. Leva-nos a 
repensar na necessidade, talvez, da repetição de modelos vistos ou vividos como única proposta metodológica deixando pouco ou nenhum espaço para a objetivação do "eu". Jung (2000, p.166), pontua que:

a personalidade (ou seja, o "si-mesmo") encontra-se ainda no estágio da pluralidade, isto é, um eu talvez esteja presente, mas ainda não pode experienciar a sua totalidade no quadro de sua própria personalidade, a não ser no âmbito da família, da tribo ou da nação; encontra-se ainda no estágio de identificação inconsciente com a pluralidade do grupo.

Tal afirmação reflete que a uniformidade pobre do grupo ainda esteja presa à pluralidade uniforme do mesmo, isto é, cada indivíduo não experiencia ainda sua própria personalidade.

\subsection{Propostas de atividades}

\section{Proposta 1}

- objetivo: "a busca do eu" versus a necessidade imposta de agradar a todos.

- atividade: teatralização da história pelo grupo e confecção do crachá.

- história: Bom dia todas as cores.

- desenvolvimento da atividade

O grupo ouviu a história em roda. Logo após, organizou-se a distribuição dos papéis a cada elemento do grupo.

Depois da teatralização da história, o grupo produziu o crachá e comentamos seus pontos pertinentes, como por exemplo, uma fala do grupo: "ele mudava de cor para agradar os outros".

Com relação ao teatro em si, alguns alunos conseguiram se colocar lembrando-se das falas; outros, porém, tiveram uma representação gestual e de fala bastante pobres. Não obstante, demonstraram a vontade em realizar este teatro.

A proposta acima citada surgiu da necessidade que vejo dos alunos estarem sempre tendo que agradar a todos - pais, professores, etc, deixando um pouco de lado suas próprias vontades e desejos. Este trabalho se faz necessário em virtude de se desenvolver a mudança de postura frente à uma reflexão do que se pode ou não fazer de maneira equilibrada, para que as vontades pessoais assim como os desejos, não sejam postos de lado em detrimento da vontade dos outros.

Refere-se, portanto, à uma busca do "eu", daquilo que se é, da individualidade que merece respeito e que, para crianças com necessidades educativas especiais, torna-se imperativo para a vivência com os adultos, à vivência no grupo escolar e familiar. Uma vez desenvolvido o respeito por si próprio fica muito mais fácil "agradar os outros", já que seus desejos e vontades não foram suprimidos e uma busca harmoniosa e equilibrada pode ser instaurada.

Apesar do manifesto desejo em participar, muitos, como outrora citado, não deram conta da representação, outros, porém, enriqueceram seus personagens com repertório gestual grande e não se prenderam aos elementos do texto, revelando desenvoltura na fala. 
Foi o caso do A1 que, representando o sapo da história, preocupou-se muito com as falas e também questionou-me sobre "como era a voz de um sapo de verdade" ou seja, que sons um sapo emite e ainda disse-me "ele pula assim não é?" Remeteu-se ainda ao personagem, numa preocupação de mudar seu tom de voz para um mais grave e grosso.

Todo este empenho suscitou em alguns colegas do grupo a preocupação com seus personagens, embora alguns tenham conseguido falar, outros emudeceram e ainda teve quem apresentou um repertório gestual empobrecido.

O fato do A1 preocupar-se em como seria a representação do sapo, o levou a pensar num sapo real e como este se comporta (pular, emitir sons) despertando sua criatividade na situação lúdica que o encenar propicia. Configura-se, desta forma, que recursos artísticos terapêuticos despertam nos alunos sua capacidade criativa numa vertente em que encontramos respostas de que o processo criativo pode ser construído. Valida, desta forma, a premissa de que propiciar espaço de criação, um espaço reservado para os sonhos, faz suscitar a capacidade imaginativa e criativa dos alunos.

O processo criativo como algo a ser construído possibilitou no espaço das oficinas enxergar cada ritmo, cada aluno em especial. Denota assim que cada um possui também um ritmo próprio e maior ou menor facilidade em se colocar, em se achar no seu papel individual de construção.

O A6, por exemplo, demonstrou uma preocupação excessiva com a representação de seu personagem, fazendo-o repetir a fala dos outros alunos sem se dar conta das falas de seu próprio personagem. Em contrapartida, o A5 lembrou-se das falas, mas não se preocupou com a representação gestual e o quanto isto poderia enriquecer sua atuação. Aqui claramente colocada, vê-se a necessidade de se integrar fala e repertório gestual na representação teatral. $\mathrm{O}$ teatralizar de histórias pode conferir, a cada um destes indivíduos, maior unidade em seus papéis criativos/imaginativos não só do representar uma história, mas tendo como pano de fundo representar conflitos e sonhos.

\section{Proposta 2}

- objetivo: "busca de sonhos" e criação de um jardim

- atividade: criação do jardim

- história: Romeu e Julieta

- desenvolvimento da atividade

Ouvimos a história em roda na sala e nos deslocamos para um espaço semi-aberto da escola - a horta. O grupo estava muito agitado e foi um pouco difícil organizá-lo.

Dispusemos todo material numa mesa grande, onde os integrantes puderam escolher o que usar. Num primeiro momento ficaram bastante inseguros até que decidiram pintar suas caixas. Depois das caixas pintadas, cada um foi enfeitando-a como desejou. Para isso usaram contas, botões, lã, palitos diversos, massa de modelar, purpurina, lantejoula e palha de madeira além de areia e pedriscos.

Alguns alunos demoraram muito para começar seu jardim. Sentiam necessidade de vir até o professor e perguntar o que deveriam fazer, quais materiais usar, etc - o professor dizia sempre que o jardim era dele e, desta forma, deveria escolher os materiais e enfeitá-lo como quisesse. 
Nesta oficina, percebi muito claramente a necessidade de se trabalhar mais a autonomia destes alunos em virtude de eles não quererem ousar, não desejarem, de repente, decidir algo sozinho (ou não conseguir?) necessitando sempre de aprovação prévia ou orientação mais diretiva.

Um ponto que chamou bastante atenção nesta oficina, foi o fato de um dos alunos (A10), após concluída sua atividade, escondê-la colocando muita palha de madeira - cobrindo tudo além de pedriscos. Indaguei-o sobre o que havia debaixo daquilo tudo e ele me respondeu estarem as florzinhas para nascer, o que deixou-me mais aliviado, pois pude perceber que embora tudo estivesse seco e sem vida, ela, a vida, estava sob as palhas de madeira. Existe ali algo que ainda vai brotar, viver e crescer e com certeza frutificar.

O A1 ficou bastante empolgado com a idéia de se construir um jardim e empenhou-se em encaminhar suas idéias e fazer a coleta de material. Assim, relatou-me que em seu jardim havia muitas flores, uma casinha representada por uma conta triangular, passarinhos, cabrinhas e um beija flor. Por fim, afirmou que seu jardim é "bom, bonito e legal" e ainda que "tem frutas e sorvete". Mais tarde completa: "no meu jardim tem gente" - japoneses (contas pretas colocadas em pé). As lantejoulas rosas são "as saias das japonesas" e ainda "uma criancinha japonesinha também". Digo que tem muita lantejoula rosa em seu jardim no que ele logo explica: "tudo é saia, tem bastante mulher". Ainda em sua explicação, coloca que "tem um carro no jardim, veio lá de São José dos Campos e quem está nele é um japonês". Talvez esta invasão japonesa em seu jardim se deva ao fato dele morar próximo a uma colônia japonesa num bairro afastado da cidade.

A riqueza de detalhes descrita acima, contrapõem-se na narrativa do A6 que assim expressa seu jardim: "os palitos sou eu e os botões são tudo". Ainda que sintético, seu relato é forte e pontual. Já a A7 coloca que, sobre o fundo preto de seu jardim, "tem estrelas e flores".

A confecção do jardim ofereceu à estes alunos a possibilidade criativa e confortável de se criar um espaço próprio, único, mesmo para quem não conseguiu expressar em palavras aquilo que realizou, como foi o caso do A8. Já o A4, coloca que: "tem flores e árvores, a cobra está dormindo no jardim, tem pedras onde batem as águas e tem um passarinho". Que forças e energia criativa reserva esta cobra que ainda dorme no jardim?

Segundo Ostrower (1977, p.11),

Criar é, basicamente, formar. É dar uma forma a fenômenos que foram relacionados de modo novo e compreendidos em termos novos. Nas perguntas que o homem faz sobre o mundo e nas soluções que encontra, nas suas ações bem como na própria experiência do viver, o homem sempre forma.

É perceptível o empenho que os alunos tiveram em fazer o jardim, verbalizando idéias do tipo "eu vou pintar primeiro", "vou usar azul" ou "acho que vou querer massinha", enquanto uns poucos observavam antes de iniciarem seus trabalhos.

Nisso, Païn; Jarreau (2001, p.67) colocam que:

de um ponto de vista subjetivo, a produção se coloca, como discurso entre o eu e o outro, entre o sujeito e o código. Ela é a coisa que se distancia do sujeito para fazer-lhe imagem e que pode se tornar, para o outro, objeto a ser visto e admirado. 
Assim sendo, a proposta de se criar um jardim remonta a idéia de ressignificar termos já compreendidos numa nova perspectiva do construir, remetendo a capacidade criativa inerente de todos os indivíduos.

Cabe-nos perceber que a capacidade criativa do grupo está intimamente ligada a sensibilidade do construir seus jardins, seus espaços e neles poder encontrar beleza, cores e flores.

Desta forma, Ostrower (1977, p.12) salienta que:

Inata ou até mesmo inerente à constituição do homem, a sensibilidade não distingue somente artistas ou alguns poucos privilegiados. Em si, ela é patrimônio de todos os seres humanos, ainda que em diferentes graus ou talvez em áreas sensíveis diferentes, todo ser humano que nasce, nasce com um potencial de sensibilidade.

Compreendemos que tanto o potencial sensível pode ser expandido como o processo criativo. Em diferentes graus, vemos que a criatividade de um indivíduo difere de outro. Não mais nem menos, todos têm necessariamente capacidade de desenvolver suas potencialidades latentes.

\section{Proposta 3}

- objetivo: harmonização do grupo, respeito a si próprio e ao grupo.

- atividade: construção de móbile de borboletas e pintura no rosto.

- história: A primavera da lagarta.

- desenvolvimento da atividade

Ouvimos a história em roda na sala e nos organizamos para o desenvolvimento da atividade. Devido à dificuldade motora do grupo, trabalhamos com moldes para o desenho em TNT. Por se tratar de um tecido firme, alguns alunos necessitaram de auxílio para o recorte. A pintura foi feita com guache de cores variadas - o TNT fixa muito bem tintas - recebendo após a secagem enfeites de lantejoula. Cada aluno produziu três (3) borboletas para confeccionar um móbile na vertical.

Ocupamos as quatro horas da manhã para realizar esta atividade e ainda não foram suficientes, carecendo de parte da manhã seguinte para o término. Da mesma forma, a pintura do rosto realizou-se após o término do móbile. Para a pintura do rosto, os alunos escolheram pintar a borboleta, onças e o palhaço.

Enquanto produzíamos conversamos muito sobre a história - que já conheciam - e fomos nos colocando de tal forma que pudéssemos perceber em nós os distintos papéis que aparecem nesta pequena história. Assim como é necessário ter paciência com as lagartas se quisermos conhecer as borboletas, é necessário ter paciência com o amigo que é mais lento, que apresenta maior dificuldade para alguma atividade em específico, é necessário conhecer antes de julgar etc. a intenção maior do uso desta história, é a facilidade textual que se apresenta acompanhada de uma música bastante agradável que todos curtem muito. O cerne destas conversas informais, enquanto produzíamos, era fazer com que cada um de nós refletisse sobre suas atitudes diante do 
grupo, o que pode fazer para ajudar o outro e como concebe sua própria situação perante o grupo.

Apesar do tema proposto ter transcorrido de forma tranqüila, alguns alunos parecem ter ignorado o que nos propusemos nesta atividade, ou seja, a harmonia do grupo frente ao respeito aos outros e a si próprios.

O A4, sujou propositadamente minha camisa com tinta guache laranja sem que eu percebesse de imediato - abraçou-me como de costume e se retirou. Estranho como não percebi de imediato sua intenção, pois não é a primeira vez que faz isso. Vejo que é um aluno que não consegue conter suas manifestações de carinho e de ataque, numa proporção mais equilibrada. Tendo perfeita noção de suas atitudes, tende sempre a incorrer no erro do desagradar, provocar, ser inconveniente. Segundo Ostrower (1977, p.24),

(...) o abraço se ligará ao que talvez esperássemos acontecer e não aconteceu, a quem deu e como foi dado, a toda uma sequiência de fatos e sentimentos ocorrendo na ocasião. Fazem parte da ordenação percebida, da maneira como as coisas naquele momento se interligaram.

Retomando o seu abraço, o A4, talvez quisesse suscitar em mim algo como o desconforto e desagrado - o que de fato conseguiu. Assim, Ostrower, (1977, p.24) continua: “(...) Mais do que um simples "abraço" teríamos um contexto que se configurou em torno de um conteúdo significativo e se nos comunicou através da forma precisa em que o percebemos."

Tendo em vista o contexto desta oficina - respeitar a si e ao outro - creio que sua atitude remonta ao fato de que ainda não percebeu ou ordenou suas atitudes de respeito frente aos demais membros do grupo. Sua atitude - o abraço - veio encobrir sua real vontade em me contrariar - manchar a camisa. Por outro lado, este acontecimento propicia material para o dialogar. Sua ordenação atitudinal oferece conteúdos através da objetivação do ato do abraçar, sinalizando que algo ainda está fora de seu controle.

Dentro desta mesma perspectiva, o A1, machucou uma colega espetando-lhe um palito pontiagudo no braço. Talvez, ambos necessitem de um amadurecimento maior para compreender melhor como se estabelecem as relações dentro de um grupo e quão necessárias elas são para vivermos de forma mais harmônica, resguardando diferenças individuais.

Ostrower, (1977, p.130) explica que:

o indivíduo amadurecendo progressivamente, se diferencia dentro de si e, em níveis coerentes embora mais complexos, se orienta em seus componentes diferenciados. Alcança novas formas de equilíbrio interior. O processo de maturação envolve, pois, uma unificação em maior diversificação; envolve na busca de identidade a possível individuação da personalidade. 
Mais que amadurecer e construir o processo de individuação, há de se pensar numa forma de canalizar toda essa energia para a construção do processo criativo ao qual nos dispusemos fazer.

A propensão natural há de ser o processo de diferenciar-se do coletivo e em segunda instância, ordenar-se a fim de conseguir níveis cada vez mais hegemônicos de criação, maturidade e equilíbrio para sucessivos novos ciclos.

A pintura no rosto, feita com o grupo, permitindo-se colocar como um animal, fez surgir diversos sentimentos dentre eles, a fragilidade, - como a borboleta em seu vôo tranqüilo, calmo e leve - animal frágil, a borboleta requer cuidados ao toque, animal alado, a borboleta requer espaço para voar, requer um jardim que ofereça flores, centenas delas para alimentar-se e ordenar seu ciclo de criação. Os alunos pintados borboletas, tiveram a dimensão destes sentimentos enquanto borboletas despertando, desta forma, uma capacidade imaginativa enquanto seres alados que podem alçar vôos por mundos desconhecidos e deles colher o alimento necessário ora depositados no ato de fazer e criar que contribuirá enquanto indivíduos sociais coletivos e únicos, numa vertente que sustente suas capacidades de relacionamentos, comunicação e expressão. Desta forma, escolheram o "brilhinho" (lantejoula) para enfeitar suas borboletas. Imagino que cada um de nós tenha um brilho especial para compartilhar no imenso jardim do mundo. Sendo assim, a dinâmica deste processo de construção da criatividade concebe aos diferentes indivíduos a sua existência concreta e útil de brilhar, de ser diferente assumindo um lugar que não é mais ou menos, mas que é de forma imperativa e única, lugar onde é possível além de criar ter brilho próprio.

\section{Proposta 4}

- objetivo: respeito à diversidade

- atividade: construção de bonecos de pano e montagem de texto coletivo

- texto/livro: Diversidade

- desenvolvimento da atividade

Lida a história em grupo, partimos para a montagem do texto coletivo concomitante à análise dos diferentes tipos de personagens existentes no texto. Paralelamente aos tipos conhecidos do texto, nos preocupamos em nos observar para percebemos nossas diferenças. Desta forma o grupo pode refletir sobre suas diferenças aparentes e não aparentes e também conhecer uma vez mais a necessidade de se respeitar o outro porque como diz o texto, "diversidade é que é legal".

Ressaltamos, desta forma, não só a necessidade de se respeitar o outro, mas de aprender com ele, de crescermos juntos, de trocar. A diversidade aqui enfocada, não é apenas a étnica, mas a de valores culturais e familiares além dos religiosos.

Quanto à confecção dos bonecos, primeiramente o grupo escolheu as cores e pintou o tecido. Depois disso, tive que auxiliar cada um na amarração que envolveu a confecção dos bonecos. Fizemos as cabeças, mãos e pés com bolinhas de isopor em tamanhos diferenciados. A amarração surge como um desafio motor para a turma. Com a cabeça pronta, pintaram o rosto do boneco, aplicando-lhe olhos, boca e nariz. Desta forma pudemos pensar em como seriam os cabelos e optamos pela lã nas mais variadas cores - rosa, vermelho, amarelo e marrom. 
Mostraram-se ansiosos para levá-lo para casa. Para alguns este boneco tornou-se o brinquedo que vem e volta na mochila, assim como um companheiro mesmo. Outros relatam que ele está no quarto ou junto de outros brinquedos.

A construção dos bonecos, tendo como pano de fundo, a diversidade formativa do grupo e concomitante o fator do "eu" como ser único que componho este grupo, faz pensar que valores e contextos culturais em muito são pertinentes à um trabalho como este. Assim:

A maneira pela qual o indivíduo aborda e avalia certos problemas traduz, sem dúvida, algo de exclusivo de sua personalidade. Reflete anseios e convicções de caráter particular a partir de suas vivências também particulares. Reflete uma experiência imediata do viver, experiência que é nova e única para cada ser que vive e que é reestruturada cada vez com a própria vida. (OSTROWER, 1977, p.101)

Isto é pontuado de maneira muito clara pela autora. Mesmo no momento da construção dos bonecos, os diversos indivíduos tendem a construir-se através dos bonecos que ganham vida, que ganham nomes, que adquirem sentimentos e características particulares e que em segunda instância, refletem o nicho social ao qual os participantes estão inseridos.

Desta maneira, foi possível ouvir do A10 que "ele é bonito, gosto dele", depois ainda com seu boneco entre as mãos contemplou-o mais uma vez e deu-lhe um beijo. Existiu desta forma, a preocupação em construir um boneco que refletisse não só as características físicas como cabelos, olhos e boca - mas de lhe atribuir valores outros, além do estético. Na elaboração e construção do boneco, ouve-se comentários do tipo: "ele é meu amigo", "gosto dele", "ele vai dormir comigo", "preciso escolher um nome", "é meu amigão", etc.

Diante destas explicitações enxergamos a necessidade, inerente aos diferentes indivíduos, de se diferenciarem do coletivo - consciente ou não - esta necessidade remonta também em ordenar-se e reordenar-se sempre, uma vez que a vida apresenta-se em ciclos, propiciando um amadurecimento psíquico que reflete crescimento e transformação.

É Ostrower que tão bem explica tais pensamentos:

Crescer, realizar potencialidades, definir-nos em nós, conhecer-nos melhor, identificarnos coerentemente, são anseios tão absolutos, tão claros e evidentes em si, que dispensam qualquer explicitação. E ninguém se admira das consequiências trágicas da não-realização do homem dentro do que lhe seria possível: o vazio da vida, a apatia, a falta de respeito pelos outros (já que tão pouco fora respeitado em seu próprio potencial) e, quando não pior, um revide violento e brutal contra si ou contra os outros.

Portanto, construir um "boneco bonito" e tê-lo como "amigo" nos possibilita pensar que o desenvolvimento de potencialidades individuais está sendo trabalhado através desta oficina, assegurando o fazer e o construir do processo criativo, um vínculo que assegura a compreensão e identificação consigo mesmo.

Ainda que o processo criativo da construção de bonecos não tenha suscitado nada de extraordinário em termos da sua construção, ou seja, no que se refere ao uso de materiais alternativos, olhos diferenciados, efeitos de cabelos crespos ou lisos, detalhes nas roupas - além dos coloridos etc, deu-se vazão a um outro ponto de criação que é a imaginativa, na atribuição de 
nomes e sentimentos. Leva-nos à refletir desta forma, que esta oficina revela-nos uma abertura dentro do processo criativo em si, que carece sempre de aprimoramento, adequação de técnicas que preservem e ampliem a manifestação de potencialidades.

\section{Proposta 5}

- objetivo: despertar a capacidade criativa enquanto energia necessária para a realização de sonhos

- atividade: confecção da caixa de bolo

- desenvolvimento da atividade

Esta atividade teve enfoque bastante coletivo. Escolhemos uma caixa de tamanho médio para que pudéssemos enfeitá-la com os ingredientes que compõem o bolo, ou seja, ovos, trigo, açúcar etc. Forramos, externamente, a caixa com papel espelho colorido e aplicamos os recortes dos ingredientes sobre o fundo. Usamos encartes de supermercado e desenhos realizados pelo grupo para enfeitarmos a caixa.

Depois da caixa enfeitada, pedi para que o grupo saísse da sala para colocar os pedaços de bolo de chocolate dentro dela, amarrando-a com fitas verde, rosa e amarelo. Na volta dos alunos, organizamos um círculo e colocamos a caixa no centro. Acendemos uma vela e começamos a conversar sobre todos os ingredientes do bolo, relacionando-os com nossos sentimentos de amor, esperança, partilha, etc. Para que o bolo cresça, por exemplo, é necessário o fermento e o forno quente, assim, para que cresçamos capazes de amar, sermos felizes e criar laços fraternos, é necessário que o nosso fermento seja o amor aquecido no forno de nossos corações.

Isto explorado, pensamos juntos na roda, numa fonte de energia de grande calor e luz. Imaginando o sol, estendemos nossos braços e com nossas mãos espalmadas, mandamos essa energia para a caixa de bolo para que "nosso bolo" pudesse crescer, ficar saboroso.

Assim, cantamos parabéns e apagamos a vela. Criou-se uma atmosfera de expectativa com relação à caixa de bolo, suscitando comentários do tipo: "será que o bolo cresceu?" "tem bolo de verdade na caixa?"

As fitas foram lentamente removidas, aumentando a expectativa do grupo. Uma a uma, foram retiradas. Bocas abertas e olhos bastante arregalados revelaram o espanto e a surpresa provocada pelo brilho do papel alumínio envolvendo os pedaços de bolo. As falas nesse momento foram variadas: “É bolo mesmo?", "É de verdade?”, “A gente fez mágica?"

Por certo, esta atividade suscitou muito da capacidade imaginativa e criativa do grupo empenhados em realizar a caixa para o bolo e mais ainda, em fazer a mágica de transformar os ingredientes num bolo verdadeiro, criado com a energia que nos move a todos: esperança e amor.

Despertar a capacidade criativa nos mais diversos indivíduos, nos leva a crer que entramos em sintonia com nossa própria realidade criativa e que no grupo vem suscitar a troca e o enriquecimento das partes atingidas.

Deste pensamento, Ostrower (1977, p.143) afirma que "Ao criar, procuramos atingir uma realidade mais profunda das coisas. Ganhamos concomitantemente um sentimento de estruturação interior maior, sentimos que nos estamos desenvolvendo em algo essencial para o nosso ser." 
Retomando nossa oficina, podemos ser "mágicos" que transformam sentimentos em coisas boas e agradáveis, "fazemos de verdade" a transformação necessária para o viver coletivo saudável frente as nossas realizações pessoais.

Com relação a existência individual no grupo, Ostrower, (1977, p.143) ainda nos revela que:

(...) Daí se torna tão importante para o artista ou para qualquer pessoa sensível, saber do trabalho dos outros, ter contato com seres criativos, não só no sentido de uma rivalidade, mas no sentido de um crescimento interior que também em nós se realiza quando podemos acompanhar a realização de outro ser humano.

A dimensão "mágica" e criativa de e construir a caixa de bolo num fazer coletivo nos coloca em sintonia com sentimentos pessoais e nos revela sentimentos dos outros integrantes do grupo. Juntos realizam "a mágica" necessária para que se possa crescer entrando em contato com a capacidade criativa do outro que é diferente da minha e que em função disso pode acontecer de me completar e desta troca haver o auxílio necessário para o desenvolver-se mutuamente.

Pensando em níveis gradativos de integração, a oficina ofereceu isto da maneira como foi articulada pelos membros do grupo. Vemos que a construção da caixa remonta construções individuais que sofrem necessariamente reflexos do coletivo e que em segunda instância faz brotar algo novo. "Nosso bolo", portanto, ganha forma, textura, cor e sabor, assim como integramos conhecimentos para construir algo físico do objeto (concreto), surpreendemo-nos com a surpresa revelada pelo espanto da "mágica" em si. Por certo o "mix" de diferentes ingredientes e sensações, assim como a possibilidade interacional proporcionada pelo fazer resulta numa nova forma alcançada pelo grupo.

Graças a capacidade inventiva e criativa, podemos enxergar que o processo criativo gerado no grupo encontra-se em níveis diferentes para cada integrante do grupo é de tal forma que algumas falas revelam - "quando a gente vai fazer mágica de novo?"

Canalizar energias para o processo de criar, garante resultados a que nos propusemos olhar. As técnicas e recursos expressivos oferecidos nas oficinas de criatividade despertaram, nos diferentes indivíduos, necessidades de auxílio no fazer e desenvolver de seu processo individual.

Nesta oficina, o grupo verbalizou o tempo todo a necessidade dos diferentes ingredientes para se fazer o bolo. Transferidos aos nossos sentimentos, para fazermos o "bolo" das nossas relações pessoais e interpessoais, o grupo, foi capaz de criar uma "receita" contendo nossos sentimentos para fazer esse bolo e mais ainda - revelando-nos que o fermento natural - para que este bolo sempre cresça - é o amor e a esperança - presentes em todas as nossas relações para o construir e edificar mundos e sonhos.

\section{Quanto à seqüência de atividades e os avanços criativos alcançados pelo grupo}

Pensamos numa seqüência de atividades onde pudéssemos ler os avanços do grupo quanto ao processo criativo e os avanços individuais no que se refere à: interação social, a autonomia e a organização dos mesmos. 
Desta forma, as propostas foram pensadas de tal forma que pudéssemos conciliar o desenvolvimento dos itens acima citados justapondo-os a teoria que fundamenta este trabalho.

Na proposta 1, (cf. p.25) o que buscamos além da interação social, foi a capacidade argumentativa dos membros do grupo, a capacidade de lidar com suas frustrações e a representação de cada personagem escolhido. Dentro desta proposta, enxergamos a capacidade imaginativa de alguns no tocante a sua representação gestual e de fala, como foi o caso do A1 mudança de voz, o pular do sapo etc.

Explicita-se assim, "a capacidade de simular sentimentos e de verbalizações próprias aos personagens da história (utilização de significantes) ou, ao contrário, sua transformação em relação à história lida" (PAÏN; JARREAU, 2001, p.144).

Esta preocupação refletida pelo A1, partiu de uma ação individual sem interferência alguma do professor. Porém, sua ação não foi suficientemente forte a ponto de contagiar outros elementos do grupo, o que nos remete a pensar uma vez mais que os indivíduos processam os estímulos e as informações de maneiras diferentes, revelando estágios de maior ou menor avanço criativo em vias de construção.

Desta premissa, a proposta 2 oportunizou um espaço mais intimista de criação. Mesmo estando envolto pelo grupo e dele ter recebido interferência/ajuda, a criação do jardim foi realizada individualmente.

Assim, Ostrower (1977, p.75) nos esclarece que:

(...) sua orientação interior existe, mas o indivíduo não a conhece. Ela só lhe é revelada ao longo do caminho, através do caminho que é seu, cujo rumo o indivíduo também não conhece. O caminho não se compõe de pensamentos, conceitos, teorias nem de emoções - embora resultado de tudo isso. Engloba antes, uma série de experimentações e de vivências onde tudo se mistura e se integra e onde a cada decisão e a cada passo, a cada configuração que se delineia na mente ou no fazer, o indivíduo, ao questionar-se se afirma e se recolhe novamente das profundezas de seu ser. O caminho é um caminho de crescimento.

Compreendemos um pouco melhor, depois deste pensamento da autora, a atitude do A10 no momento em que estava pronta sua produção, escondê-la com palha de madeira. Ocultando talvez,um caminho que ainda não esteja pronto para trilhar, mas revelando-nos a certeza de que existe um caminho e ainda que dentro desta atividade oferecemo-lhe a oportunidade de pensar e agir sobre seu caminho, construindo-o.

Já na proposta 3, o que buscávamos era a harmonização do grupo e o respeito aos outros e a si mesmo. Enfrentamos algumas situações desafiadoras dentro do grupo neste trabalho em específico, ainda restou-nos a possibilidade de experienciar que: "a maneira pela qual o indivíduo aborda e avalia certos problemas traduz, sem dúvida, algo de exclusivo de sua personalidade. Reflete anseios e convicções de caráter particular a partir de suas vivências também particulares." (OSTROWER, 1977, p.101).

Cremos que a atitude do A1 e do A4 de machucar uma colega com um palito pontiagudo e de sujar-me com tinta guache propositadamente, nos faz pensar em elementos pertinentes à suas personalidades e em como lidam com eles. Mais que isso, traz ressonâncias particulares quanto à um universo particular construído a partir de valores e contextos culturais também particulares que ora repercutiram no grupo. 
A proposta 4 trouxe a preocupação que temos com a diversidade nos diversos grupos sociais e como se estabelecem e de que forma (se necessário), harmonizarmos nossas convivências. Assim, a criação dos bonecos, apoiado num texto bastante lúdico, ofereceu-nos a possibilidade de conferirmos os diferentes tipos existentes na história transferindo-os para $o$ contexto do grupo.

Diante desta proposta, Ostrower (1977, p.103) nos faz pensar que:

(...)cada homem é um indivíduo. Ao agir, inter-age com o mundo. Eventualmente ele agirá sobre o próprio contexto cultural. Por motivos talvez de ordem puramente pessoal e correspondentes a um potencial específico seu, podem desencadear-se no indivíduo respostas que, à medida em que aprofundam certos valores e certas possibilidades existentes no contexto em que vive, modificam essas possibilidades para rumos diferentes.

Estando esta dimensão consciente ou não, no fazer dos bonecos, ouviu-se no grupo comentários do tipo: "ele é meu amigo" ou "gosto dele" - explicitado pelo A10 através de um beijo após contemplação de seu "boneco-espelho". A maneira como encerra sua atividade, remete-nos que o A10 parte de um mundo particular onde podemos entender que aceitação, ressonância afetiva e um lugar social estão garantidos para além do grupo. Construído a partir de um nicho social distinto, lemos que a unicidade do "eu" através desta proposta pode ser uma vez mais constatada, obviamente não se encerra, concorda com a premissa de que o processo de construção é dinâmico e que trabalhos outros contribuem para o avançar sempre - remetendonos aos caminhos que cada um de nós temos que trilhar e que trilhando construímo-los.

A proposta cinco nos trouxe a capacidade criativa - inerente ao homem - enquanto energia para a realização de nossos sonhos.

Possibilitou-nos alçar vôo rumo ao objetivo a que nos propusemos neste espaço - tempo mágico de criação. Com relação ao potencial criativo, Ostrower (1977, p.27) salienta que:

(...) o potencial criador elabora-se nos múltiplos níveis do ser sensível - cultural consciente do homem, e se faz presente nos múltiplos caminhos em que o homem procura captar e configurar as realidades da vida. Os caminhos podem cristalizar-se e as vivências podem integrar-se em formas de comunicação, em ordenação concluídas, mas a criatividade como potência se refaz sempre.

Findando as oficinas, a proposta 5 nos trouxe a dimensão mágica de se construir uma caixa de bolo e dela fazer surgir os pedaços também mágicos em sabor e cor de um bolo real, confirmando-nos a possibilidade de que os membros do grupo podem usar de seu potencial criativo não apenas para criar uma receita que extrapole para além dos ingredientes de um bolo. Em uma configuração maior, correlaciona-se esta mágica transformação ao "bolo" de nossas relações interpessoais. Conferimos desta forma cores e sabores que revelaram que a produtividade de cada indivíduo jamais se esgota - amplia-se.

Estes ganhos nos fazem pensar que os processos de criação desenvolvidos em cada uma das oficinas oferecem uma possibilidade infinita de criação. A cada novo ganho, abrem-se as portas de um novo fazer criativo, colaborando sobremaneira para o crescente reabastecimento da 
energia e potencial do criar, revelando surpresas - "fizemos mágicas", "fizemos de verdade". Cremos que a maior mágica deva ser a canalização das energias que irão perfazer as concretizações dos sonhos.

\section{Avanços individuais quanto à interação social, autonomia e organização}

Tentaremos aqui, destacar alguns pontos onde se possam ler uma mudança de postura frente às atividades propostas que puderam revelar maior interação social, autonomia e organização com relação aos avanços individuais nos diversos membros que formam o grupo. $\mathrm{O}$ lugar para a leitura destes fatores ocorreu em cada oficina de criatividade realizada pelo grupo pela observação direta no decorrer das mesmas e também pela verbalização de alguns no decorrer das atividades.

Para efeito didático, usaremos a nomenclatura "ALUNO", acompanhado de um número que se seguirá até dez (10) em ordem crescente. Deste modo teremos então: ALUNO 1 (A1), ALUNO 2 (A2), ALUNO 3 (A3)...... ALUNO 10 (A10).

O A1 vem de uma família bastante perturbadora para ele e seus irmãos. Estuda na mesma escola um irmão mais velho também com déficit intelectual. Sua mãe também apresenta algum déficit intelectual e seu pai, algumas vezes costuma vir para a casa alcoolizado e nestes casos torna-se violento. Dentro desta perspectiva, sua dinâmica pessoal oscila entre a falta de limites pela incapacidade da mãe em lidar com suas vontades e a severidade do pai - que bate muito e dialoga pouco.

Com relação à interação social, seu comportamento também tende a oscilar. Ora é capaz de comover-se com o colega a ponto de empenhar-se em ajudar, noutras situações, através da força bruta é capaz de bater para conseguir o que quer sem saber esperar. Isto aconteceu com os materiais em uso nas oficinas, com os brinquedos da caixa de brinquedos, com o balanço do parque. Porém, foi possível enxergar que seu lado amigo e companheiro pode florescer mais quando diz à uma amiga "vou te ajudar" ou quando me pergunta se pode ajudar e ainda consegue reconhecer a beleza do trabalho do outro. Embora este comportamento seja oscilante, demonstra que é possível desenvolver um equilíbrio maior para a convivência em grupo e consigo mesmo. Assim, Byington (1987, p.15) coloca que: "O Eu é tão importante quanto o outro no campo psicológico, pois ambos compõem o símbolo. Nossa vivência no mundo é sempre simbólica, e a partir dela é que separamos, ou seja, discriminamos os fatores subjetivos e objetivos que determinam nossa conduta."

Ainda no proceder da formação do "eu" e do "outro", numa vertente dialética que dialoga portanto entre os aspectos subjetivos e objetivos da construção das relações, a autonomia desenvolvida pelo aluno A1 pode ser vista, quando consegue frente as atividades propostas, decidir quais objetos quer usar e como usá-los. Das observações feitas pude perceber o quanto se dispunha a pensar, decidir e ponderar sobre a melhor forma de fazer determinada atividade. Preocupava-se algumas vezes em se reportar a mim e perguntar - "está certo?" ou "eu quero assim." Isso denota grande seguridade no fazer, no construir e que materiais usar frente às atividades. Porém sua organização e cuidados com o material ainda refletem carência organizacional. Talvez essa carência em organizar materiais e com eles ter cuidado ao manuseio, sejam reflexos de sua própria dinâmica familiar, pois não existe por parte da família uma organização e cuidados com a criança relativos aos seus materiais pessoais, sua aparência pessoal em termos de higiene e muito menos em vistas organizacionais quanto a uma dinâmica 
diária que suscite evolução quanto a estes aspectos. “(...) a psique individual ou coletiva é um organismo que está sempre em desenvolvimento, a fim de realizar seu potencial genético ou arquetípico." (BYINGTON, 1987, p.20). Isto posto, a incidência de oficinas de criatividade junto ao apoio familiar podem revelar o desenvolvimento operacional quanto a organização do A1.

A2 - Trata-se de uma aluna nova na escola. Sua chegada foi bastante conturbada e difícil. Fez tudo o que pode para não ficar - chorou, fez birras diversas etc. tivemos que "negociar" muito para que entrasse na sala e conhecesse a turma. Figura arredia, mandona e muitas vezes mal humorada. Apresentou grande evolução dentro do grupo quanto à interação social. Nos primeiros contatos, não nos encarava, nem aceitava o toque e ainda hoje só o aceita do grupo do qual faz parte. No decorrer das oficinas, muitas vezes foi necessária uma aproximação maior do outro para desenvolver as atividades. Percebi que sua postura sofreu mudanças significativas principalmente no que diz respeito ao toque. “(...) A psique é como uma semente que aproveita a terra, a chuva, o vento, os insetos e tudo o que acontece de bom ou de mau para formar a árvore." (BYINGTON, 1987, p.20).

A interação com o grupo propiciou então esse aproveitamento da troca, da partilha e da busca no realizar das atividades, para que a A2 pudesse harmonizar-se melhor no grupo. Embora seja "mandona" seu relacionamento melhorou muito no sentido de que consegue deixar fazer e fazer carinho sem ser agressiva. As sementes podem estar brotando em nova terra. Porém, percebo que este ganho limita-se ainda à sala de aula com o grupo. Na escola como um todo, ainda comporta-se de forma arredia. Não obstante a sinalização de que mudanças estão ocorrendo faz-se pertinente. Sua autonomia no fazer das atividades é vista sempre. Organiza-se bem com os materiais e concentra-se. Percebo que faz tudo a seu tempo e sem pressa. Nestes momentos de concentração, não gosta de ser interrompida e vez ou outra pede para esperar. $\mathrm{O}$ novo da escola e das oficinas de criatividade realizada com critérios próprios e organização didática revela que o "símbolo pode trazer algo novo e produzir uma desarrumação na ordem vigente" (BYINGTON, 1987, p.21). talvez essa desarrumação tenha sido necessária à A2 para poder entrar em sintonia com seus mecanismos de criação e com o grupo.

O A3 pouco fez parte de nossas oficinas. Criança super-protegida pela mãe, encontra-se sempre doente e faltosa. Dificilmente consegue vir uma semana completa. Deste quadro, resulta uma criança indecisa e frágil com relação às suas próprias vontades. Nos ganhos com a interação social, os demais alunos percebem sua ausência e perguntam porque não veio. "Está doente de novo?" - perguntam ou "ele vai perder a atividade de hoje né?" sua faltas não fizeram perder os vínculos quanto a interação social, porém, instalou-se um processo de regressão com relação ao seu desenvolvimento pedagógico. Quando indagado do porque de sua ausência, sempre responde com a fala da mãe que estava doente e teve que ficar em casa. Esta simbiose proporcionada pela relação mãe-filho, reflete-se em sua conduta perante as atividades: grande insegurança no realizar das propostas, não consegue decidir questões simples como por exemplo a escolha de materiais e tão pouco organiza-se em função do tempo e dos objetivos a serem atingidos. De acordo com Byington, (1987, p.31), "a capacidade de simbolização está inerente a um maior envolvimento com o meio para originar nossos símbolos". Assim sendo, o envolvimento com um grupo, seja ele a escola, a igreja ou a comunidade, garante a dependência necessária para a nossa formação psíquica ou seja, "nossa capacidade de simbolização é inseparável das nossas relações de dependência". Mais adiante o autor pontua que: "Independente do porque isso ocorre, o fato é que o início da estruturação da personalidade, que Freud descobriu ser tão importante para o resto da vida, opera dentro de uma simbiose com o meio, apresentando uma extraordinária dependência dele. (BYINGTON, 1987, p.31)." 
Obviamente que esta dependência do meio acontece durante toda nossa vida e não somente na infância do A3 ou qualquer outra criança. Este é um dos caminhos que a psique pode encontrar para funcionar durante toda sua existência.

O A4 é filho único. Quando de sua chegada na escola há 4 anos, soubemos pela mãe a sua frustração pelo déficit intelectual apresentado pela criança bem como da incapacidade dos pais em entendê-la e aceitá-la numa escola de educação especial. Seu envolvimento com o grupo desde então, é bastante bom. Tem uma forte postura de liderança e relaciona-se bem com todos. Possui grande autonomia no fazer das atividades, mostrando-se generoso em ajudar quem apresenta dificuldades, compartilhar objetos e até mesmo seu lanche. Tudo seria tranqüilo se não fosse o fato de não refletir mais antes de fazer algo. Quase sempre é impulsivo e bruto em suas demonstrações de carinho. Em alguma ocasiões, percebo que quer nos testar a todos quando propositadamente nos suja com guache, promove desordem no refeitório, morde a merendeira, xinga a todos sem precedentes... existe uma inquietação muito grande. Ao mesmo tempo em que apresenta autonomia suficiente para pesquisar em casa um motivo que será importante à todos, não consegue autonomamente adquirir um comportamento que não seja o de testar-nos, suscitando relações conflituosas onde não consegue ou não quer (?) perceber o quanto pode machucar, magoar ou ferir as pessoas de quem diz gostar.

Byington, (1987, p.32) observa que:

A consciência apresenta inúmeros estados de funcionamento com a idade, o estado de saúde, o momento do dia ou da noite, o tipo de atividade e inúmeras outras variáveis. Uma destas variáveis será o nosso ponto central e se refere aos padrões arquetípicos da consciência, ou seja, formas típicas de funcionar da consciência que se revelam com o desenvolvimento da personalidade em ciclos arquetípicos.

Com relação à saúde psíquica do $\mathrm{A} 4$, recentemente os pais foram chamados à escola para uma conversa com a psicóloga da instituição, a coordenadora pedagógica e o professor. A psicóloga, depois de relatar todos os aspectos do comportamento do aluno, sugeriu que ela procurasse um acompanhamento psicológico (uma vez que já fazia fora da instituição e havia parado) e também uma visita ao psiquiatra. Talvez a saúde psíquica aqui possa estar precisando de ajuda ou talvez a severidade do pai deva dar mais lugar ao diálogo. O conhecimento da vida, que orienta o ser no desenvolvimento, opera sempre de forma bipolar. "Conhece-se o Outro e suas incontáveis variáveis, ao mesmo tempo em que se desenvolve o EU". (BYINGTON, 1987, p.32).

Talvez o que falta ao A4, seja de fato entender melhor como se dá essa bipolaridade e que proveito pode se tirar destas relações quando consegue se colocar no lugar do outro, quando consegue respeitar, sentir a dor do outro em variáveis - como coloca o autor, incontáveis fazendo com que a construção de seu "EU" possa enxergar que o "OUTRO" opera de uma mesma forma, em outro ritmo, mas com as mesmas probabilidades de anseios, vontades, realizações e frustrações. Penso que falta uma maior dimensão e entendimento, identidade e diferenciação do EU - OUTRO como fenômeno análogo existente durante o desenvolvimento psicológico.

As oficinas de criatividade foram um suporte e um enquadre que ajudou-nos a formalizar e encaminhar a ajuda necessária de um profissional adequado para o auxílio do A4. Até o 
presente momento, aguardamos uma devolutiva por parte dos pais quanto ao encaminhamento solicitado em nosso encontro.

A5 - Percebo que sua interação social no grupo tem melhorado muito. Porém ainda não é capaz de assumir as coisas que faz de errado. Demora muito para assumir qualquer coisa que tenha feito e necessita sempre compartilhar a culpa com alguém.

Segundo Byington, (1987, p.34), "a formação da identidade do "EU" seria facilmente explicada pela projeção da psique sobre o mundo, seguida pela identificação". Assim sendo, costuma dizer "fui eu, mas fulano estava comigo" - necessitando de um comprometimento do outro não revela em si uma capacidade mais autônoma de ser nas relações dentro do grupo.

Diante do quadro das oficinas, apresentou grande interesse e envolvimento. Foi cuidadoso na construção de seus objetos demonstrando organização para o trabalho e autonomia quanto as decisões sobre quais materiais usar e quando. Foi capaz de selecionar os materiais previamente a construção daquilo que queria consultando-me raríssimas vezes com as perguntas - "posso usar isso?" ou "posso usar o que eu quiser?". Nesta perspectiva, organizei o material de tal forma que estivesse disponível a todos. Sempre sugeria uma reflexão - pense naquilo que vai fazer e escolha os materiais.

O mais preocupante dentro dos trabalhos do A5, é a necessidade que ainda demonstra de realizar quase tudo em parcerias com o A4. Sugeri que se distanciassem para assim não haver muita interferência em ambos trabalhos realizados. Isso de fato surtiu efeito, porém sempre ouvia suas conversas - "vou usar palitos agora, e você?" ou "você colou brilhinho no seu?" Sugeri esta interferência do afastar-se porque queria enxergar até que ponto as produções poderiam ser diferenciadas revelando algo bastante pessoal e com interferências mínimas desta troca. Embora tudo tenha transcorrido de maneira discreta, isto surtiu um efeito para com o A5. Em uma das oficinas, quando perguntei como ficaram os trabalhos e o que acharam de tê-lo feito, ele me disse - "o meu ficou diferente do dele". Esta percepção colabora para uma identificação maior dentro do grupo, revelando a priori que os trabalhos não têm necessidade de serem iguais assim como as nossas posturas dentro do grupo. Reagimos a um mesmo estímulo de maneira diferente e isto não é bom ou ruim, isso é ser aquilo que se é e como tal cada um de nós precisa encontrar seu caminho próprio no fazer e realizar das coisas.

O A6, apresenta uma ansiedade muito grande em tudo o que faz. Fala alto demais, é agitado e inquieto e em função disso, tem muita dificuldade em se concentrar e canalizar energias necessárias para o fazer das atividades. Muitas vezes parece não compreender aquilo que lhe perguntamos e também suspeitamos que pudesse ouvir pouco, revelando desta forma perda auditiva além do déficit intelectual. A fonoaudióloga da escola - por quem o A6 é atendido, solicitou exame audiométrico para eliminarmos ou conferirmos nossas suspeitas. Apesar de não responder coerentemente o exame, a médica considerou sua audição de grau normal, o que nos faz pensar mais em seu déficit intelectual e ansiedades bastante altas.

Dentro das oficinas propostas, foi capaz de entender a dinâmica de cada trabalho a que nos propusemos fazer. Revela certa dificuldade em organizar-se e decidir quais materiais e em que ordem usá-los. Necessita sempre de ajuda e sempre se reporta à uma colega em especial para executar as coisas. Às vezes, seu grau de ansiedade é tão grande que no meio da atividade me diz - "já terminei, ficou bom?" - respondo se ele não vai pintar a outra parte no que ele me diz “ah! A outra parte né? Tem que pintar?" Se não pergunta a mim, o faz para sua colega de quem é muito próximo. Percebi que com alguns poucos exercícios para relaxar, obteve grande dificuldade em se concentrar. Não obstante, empenha-se no fazer das atividades. Seus trabalhos são limpos, possuem transparência de imagens e colorido agradável ao observá-lo. 
Ostrower (1977, p.127) coloca que “(...) a criança age impulsivamente, espontaneamente para ver o que acontece. Embora sem dúvida, haja sempre curiosidade acerca das consequiências nem as próprias intenções são medidas ou avaliadas anteriormente à ação."

Penso que, assim, possamos talvez, propiciar maiores descobertas frente às oficinas, uma vez que a curiosidade promovida por ela (descoberta) possa ser o combustível necessário para o desvelar.

Parceira do A6 a A7 apresenta uma evolução bastante satisfatória quanto a sua autonomia no fazer dos trabalhos nas oficinas - seja escolhendo materiais, seja decidindo quais cores usar etc. com relação ao grupo, sua interação é ótima. Consegue relacionar-se com todos de maneira positiva e alegre. Seu empenho no realizar é notório e o faz com prazer. Sempre revela-me em seus trabalhos a satisfação - "olha o que eu fiz" ou "fiz sozinha" e preocupo-me em lhe perguntar se gostou de fazer ou se não encontrou alguma dificuldade. No tocante a explicar como elaborou seu trabalho, percebo que algo fica falho, como se houvesse um espaço de tempo perdido entre o elaborar e o executar das atividades, pois raríssimas vezes consegue explicar como fez. Percebo ainda que a elaboração de seu pensamento é no mínimo confusa e isso se repercute na linguagem. Emudece ou pronuncia palavras ou explicações não inteligíveis. Este mesmo ponto é percebido pela fonoaudióloga que a atende. Juntos discutimos muito sobre a questão da linguagem e estruturação do pensamento. Nas oficinas, percebemos uma melhora neste momento conjunto do discutir as atividades realizadas explorando cada ponto desenvolvido, cada material usado para que pudéssemos estruturar melhor sua devolutiva ao grupo e a si mesma com relação ao entendimento de suas produções. Pontuado desta forma, adquiriu maior controle ao falar e explicar suas produções sinalizando entendimento.

Nesta perspectiva, Ostrower (1977, p.129) salienta que:

(...) as alterações que ocorrem na expressividade infantil correspondem, portanto, a fase de crescimento físico e psíquico da criança. À medida que a criança vem naturalmente a se discriminar, dentro de si e em relação aos outros, também reestrutura seu potencial sensível e racional em níveis mais complexos.

Dessa forma, tranqüiliza-nos saber que o processo que ora se instaura pode ser considerado como um caminho que aponta não só para o desenvolvimento psíquico da $\mathrm{A} 7$, mas também um eixo revelador de potencialidades frente ao amadurecimento que ocorre naturalmente com as crianças, ainda que neste caso incompatíveis, idade cronológica e mental.

A chegada do A8 na escola se deu neste ano. sofreu e chorou muito para conseguir se adaptar ao ritmo escolar. Aos poucos fomos nos conquistando e estabelecendo relações de carinho e aceitação. Hoje, sua interação social pode ter ganhos ainda maiores com as oficinas de criatividade. Possui grande limitação ao se expressar, não articulando os lábios para falar de tal forma que a sonoridade de sua fala saia entre dentes. Como não foi possível neste ano ser absorvido pelo setor de fonoaudiologia da escola por motivos de vaga, no próximo ano, será atendido. Isto se deve ao fato de haver na entidade pouca rotatividade de alunos em termos de alta neste setor e de possuirmos um único profissional nesta área.

$\mathrm{O}$ enfoque primordial para o A8, foi de fato a interação social, visto que é a primeira vez que freqüenta uma escola. Oriundo da zona rural, vimos que o aluno apresenta grande quadro de privação social, onde tudo é novidade, estranheza e inquietação. Compreende pouco daquilo que lhe é pedido e ainda não consegue estabelecer parâmetros próprios onde se perceba a autonomia 
e organização para realização das atividades. Empenhou-se muito em realizar suas produções e o grupo como um todo o ajudou a elaborar seus trabalhos no sentido de motivá-lo sempre.

Assim, Ostrower (1977, p.129) nos diz "Entende-se que a criatividade infantil pode ser estimulada. O modo como se visa o incentivo do potencial infantil, reflete-se nos objetivos e nos comportamentos desejáveis estabelecidos para a criança.".

O grupo então, foi sempre o estimulador necessário para o A8. Empenharam-se inclusive de tomar conta do mesmo no sentido de pedir à ele que não mordesse as mãos (algo que comumente faz quando agitado), que não mordesse as mangas da blusa. Essa interação do A8 com o grupo, tem surtido efeito satisfatório. A aceitação do grupo bem como seus cuidados fizeram aparecer uma criança que não chora mais e que consegue ficar no período todo de 4 horas em sala de aula. Motivou-se sobremaneira nas atividades realizadas em grupo e individualmente. Conseguiu ordenar-se, portanto, dentro de uma rotina que pode ser vista também frente às oficinas. Apresentou tolerância e interesse para poder realizar as atividades. Ainda não adquiriu um controle motor com relação aos objetos. Seu toque é bruto e quase destruidor. Apresenta desta forma grande força para o pintar/ desenhar acompanhada de rigidez muscular.

Não obstante, são fatores que nas oficinas de criatividade tendem a ser amenizados, pois uma vez que conseguiu estabelecer ligações interacionais positivas no grupo, pode com certeza adquirir outros ganhos.

O A9 apresentou boa evolução com relação a interação social. Muito disso se deve ao fato da acolhida e ajuda do grupo no realizar das atividades. Embora seja capaz de reconhecer seu nome, não o escreve e também não é capaz de pronunciá-lo. Pela convivência, é possível perceber quando quer ir ao banheiro, quando quer tomar água etc. Quando quer nos mostrar algo, pega em nossa mão e nos leva até o lugar onde o que gostaria de dizer se faz presente pelo objeto e/ou situação que temos que interpretar/analisar.

Filho único é criança muito dependente no realizar das atividades mais simples como escovar os dentes, amarrar o tênis etc. A grande ênfase reforçada pelas oficinas é fazer emergir o potencial organizacional e resoluções em que a autonomia, nas situações mais simples, pudesse ser lida. Tudo transcorreu de forma lenta e difícil de ser lido/mensurado. Demorou muito para realizar alguns de seus trabalhos nas oficinas e ficou extremamente agitado quando se via sozinho para resolver se pintava ou não, bem como o que escolher em termos de materiais. A interferência do grupo foi o que mais o ajudou para as suas produções. Embora o processo tenha se dado de forma lenta e conturbada, foi capaz de responder produzindo algo que fora proposto nas oficinas. Percebo que compreende pouco do que tem que executar, talvez porque não consiga ordenar mentalmente suas ações transformando-as em imagens. Será por isso que demora tanto a executar? Será que espera para ver o que acontece para depois elaborar o seu com base no que os outros estão produzindo?

Ostrower (1977, p.130) coloca que:

(...) o indivíduo amadurecendo progressivamente, se diferencia dentro de si, em níveis coerentes embora mais complexos, se orienta em seus componentes diferenciados. Alcança novas formas de equilíbrio interior. O processo de maturação envolve, pois, uma unificação maior em maior diversificação; envolve na busca de identidade a possível individuação da personalidade. 
Nesse pensar, creio ser de grande importância o auxílio familiar dentro das conquistas pessoais que em muito ajudarão o A9 a se orientar e reestruturar dentro dos padrões de desenvolvimento de sua própria personalidade as conquistas necessárias quanto à autonomia e organização. Aqui então, constatamos que a parceria família/escola é de suma importância para a promoção do indivíduo.

O A10 tem evoluído a passos lentos dentro da dinâmica do grupo. Sua interação social ainda carece de maior estruturação, pois em algumas atividades tende a se isolar, falar ou brincar sozinho. $\mathrm{O}$ espaço das oficinas propiciou a troca e a interação do fazer das atividades suscitando maior mobilidade do indivíduo dentro dos sub-grupos da sala. Seu empenho em realizar as atividades não é grande. Possui uma apatia além do normal. Filho único por quase 8 anos, ganhou um irmão. Demorou muito a assimilar a idéia de ter um irmão, um amigo novo. Sempre dizia que era uma menina e não um menino que nasceria. A contra gosto, nasceu um menino.

É ainda, criança dependente do grupo e dos adultos para realizar qualquer coisa. Além de demonstrar pouco interesse, apresenta comportamento e fala bastante infantilizada. Apesar do enfoque organizacional que as oficinas ofereceram, isto ainda não foi suficiente para seu próprio organizar-se dentro da dinâmica do grupo. "Como essencial ciclo de crescimento e de transformação, o amadurecimento é uma necessidade do ser. Essa necessidade pode não se tornar consciente, mas em nossa vida psíquica, subjetiva, ela está sempre presente. (OSTROWER, 1977, p.130-131)."

Talvez a chegada do irmão faça com que demore mais no processo de elaboração de sua transformação rumo a um amadurecimento maior. Com ralação aos aspectos organizacionais, além do desinteresse e apatia por quase tudo, seus comportamentos nos levam a pensar que espera dos outros uma atitude que o beneficie. Permanecendo "bebezão" tem mais chances de adquirir seus ganhos através de menor esforço. Demorou muito para engajar-se na construção do objeto a que nos propusemos nas diversas oficinas. Ainda no tocante à organização, temos que insistir muito para que ajude a guardar os materiais utilizados, a cuidar do que é seu etc. quando muito cobrado, pressionado, costuma sentir-se mal, com dores no peito, choro e soluços quase compulsivos. Parece que o processo de amadurecimento para o A10 é muito lento e doloroso necessitando de cuidados e atenção para que não percamos de vista seu processo de encontrar-se.

\section{Intervenções do processo a serviço da eficiência criativa}

A minha casa aqui é pintada por fora de amarelo-manteiga e tem persianas verde-forte; fica rodeada de sol, numa praça, onde também há um parque verde com plátanos, aloendros, acácias. Por dentro é pintada de branco e o chão é de azulejos vermelhos. E por cima, o céu azul luminoso. Lá dentro posso com efeito viver e respirar e pensar e pintar. (VAN GOGH, 2004, p.49).

O que se percebe muito claramente nesse escrito de Van Gogh, é que ele conseguiu sacralizar seu espaço de criação, conseguiu adquirir um lugar seu, pessoal, imprescindível. Não nos cabe julgar as inúmeras fases de sua vida. Cabe ressaltar a veracidade de sua busca; a necessidade de perseguir seus sonhos; a busca pelos sonhos; o encontro com si mesmo.

Com efeito, penso na busca de todos nós por espaços sagrados, sacralizados por nós; construídos para que possamos alcançar e realizar sonhos; mergulhar em nossas emoções, 
transgredir as mais diversas imposições sociais e nos restabelecermos diante de nós mesmos desnudos dos medos de errar e trilhar caminhos novos, reencontramo-nos, finalmente.

Assim, podemos concluir que as técnicas em arte-terapia em muito ajudam a construir caminhos, ajudam-nos a descobrir mundos internos dantes sonhados. Propicia um mergulho intenso e revelador carregado de emoções que nem sempre esperávamos reconhecer em nós.

Para os alunos com necessidades educativas especiais que compartilharam comigo suas emoções frente aos desafios propostos, creio que em muito crescemos. Ainda vejo a necessidade que um trabalho como este pode nos ajudar - professor e aluno - a nos entendermos e nos ajudarmos nessa caminhada pela vida e pela descoberta.

Dentro dos objetivos propostos no fazer das oficinas e o material colhido, a respeito de cada etapa, em cada oficina, vemos a necessidade da continuidade do trabalho para que a construção da criatividade e o fazer criativo não deixem de crescer e frutificar.

Tal trabalho se faz necessário em virtude de se desenvolver a mudança de postura frente a uma reflexão do que se pode ou não fazer de maneira equilibrada para que as vontades pessoais assim como os desejos, não sejam postos de lado em detrimento da vontade de outros.

Refere-se, portanto, a uma busca do "eu", daquilo que se é, da individualidade que merece respeito, e que para crianças com necessidades educativas especiais torna-se imperativo para a vivência com adultos, a vivência no grupo escolar e familiar. Uma vez que se desenvolva o respeito por si próprio, fica mais fácil "agradar os outros", já que seus desejos e vontades não foram suprimidos e uma busca harmoniosa e equilibrada pode ser instaurada.

Nesta perspectiva, refletimos sobre a necessidade da continuidade de um trabalho que envolva necessariamente mais que um espaço de criação - o espaço para onde a criação adquire uma dimensão para além de seu "eu", para a troca, para o coletivo.

Pensando em pontos estruturantes que podem sinalizar a necessidade de investimento maior, quando se tem em vista a busca de avanços individuais e coletivos frente ao construir do processo criativo, as autoras colocam que:

Todas essas maneiras de abordar, organizar, trabalhar e descobrir e terminar a tarefa permitem ao paciente tirar do trabalho artístico um certo prazer, e de exercer uma forma de apropriação da emergência imagens através de sua configuração. Os obstáculos a essa conquista constituem os temas fundamentais da análise arte-terapêutica, pois eles podem ser considerados como sintomas, isto é, como comportamentos significantes de um sujeito, de sua história, de seu destino.(PAÏN;JARREAU, 2001,p.67)

Em algumas situações, o grupo foi capaz de adquirir maior controle para se organizar e produzir - nas trocas de materiais, na organização pós-uso destes materiais, na autonomia das escolhas. Creio que a organização assim como a superação de obstáculos é fundamental para a saúde do grupo e vejo que este caminho frutifica em novas posturas uma vez que sempre temos que discutir algo que afeta o grupo, ou seja, a postura de um influencia diretamente a do outro.

Conseqüentemente, a forma em que se nos apresenta um acontecimento, artístico ou não, nunca constitui apenas uma espécie de veículo para algum conteúdo que independentemente dela pudesse existir. Pelo contrário, a forma incorpora e expõe o conteúdo significativo. Comunicando-nos suas ordenações, a forma nos comunica a razão de seu ser e o sentido. (OSTROWER, 1977, p.97). 
Com relação ao teatro proposto na oficina 1, penso qua a atividade deva ser retomada com diferentes histórias e diferentes enfoques num recurso artístico pedagógico que pode levar ao desenvolvimento gestual dos alunos, da linguagem oral e expressão corporal.

Nesse suscitar dos acontecimentos das oficinas, o trabalho com bonecos fez surgir a necessidade do respeito frente a diversidade presente no grupo. Comportamentos preconceituosos (reproduzidos ou não), necessitam ser esclarecidos e solucionados, buscando desta forma a harmonização do grupo. Talvez, a repetição desta oficina, com panos maiores para a execução dos bonecos seja necessária. Acredito que assim os alunos terão menos dificuldades na confecção dos mesmos ou ainda que possam socializar mais o auxílio do fazer dentro do grupo. Desta forma, a auto-estima do colega monitor se eleva, o respeito aos diferentes ritmos pode se estabelecer e desta forma garantirmos que socializar saberes é um ganho coletivo.

Para termos esse estado de equilíbrio das coisas, Ostrower (1977, p.99), nos diz que:

O equilíbrio não anula as forças diferentes. Para o homem, em qualquer situação da vida trata-se de conviver com essas forças, viver através delas e incorporá-las com vistas a uma maior diferenciação. Com isso o homem amplia a apreensão da realidade. Quando vemos uma força expressiva, vemos em seu equilíbrio interior que as várias forças diferentes foram de algum modo reunidas e em algum ponto compensadas, adquirindo um novo sentido de unidade. $\mathrm{Na}$ forma expressiva, os elementos complexos da experiência humana não se descaracterizam, eles se esclarecem a um nível mais significativo.

Assim como nos foi possível construir uma caixa de bolo com todos os ingredientes necessários, nos será possível construir o "bolo das relações" numa perspectiva dialética frente aos diferentes elementos que compõem o padrão individual da experiência humana. Desta forma, não se trata de descaracterizar sentimentos e/ou posturas, mas ordená-los de tal forma e efeito que, se reunidos, possam sugerir um nível mais significativo e elevado das relações.

Retomando o processo de intervenção das oficinas, muito se faz necessário um repensar em como tudo se processou e que medidas podem ser executadas nas futuras oficinas.

Pensar no cuidado da elaboração e planejar, são constantes em qualquer processo onde o que se deseja seja a promoção do indivíduo rumo ao seu processo de individuação, amadurecimento, e o despertar de potencialidades.

Assim, alguns problemas de construção lógica podem ser corrigidos ou reavaliados para que não se perca o processo do construir e realizar. Isto porque alguns indivíduos apresentam uma produção "pobre" com relação a sua idade e até mesmo uma capacidade imaginativa pequena, detendo-se em elementos isolados na criação pessoal.

Os alunos com necessidades educativas especiais apresentam um déficit global de desenvolvimento e assim sendo, é imperativo pensar em atividades que promovam avanço tanto cognitivo como os de interação social e de autonomia além dos aspectos organizacionais.

Toda inibição presente no processo de construção, através de recursos expressivos, podem ser revalidados, ou melhor, trabalhados através de outras técnicas com mesmos objetivos. Assim, é possível realizar intervenções que favoreçam o crescimento e amadurecimento dos diversos indivíduos dentro das oficinas de criatividade. 
As atividades devem, portanto, suscitar um canal para que o material interno possa emergir e assim ajudarmos neste processo de elaboração simbólica que se faz presente. As atividades podem não constituir o todo do material para a representação da imagem mas, podem servir de base para onde e quando realizar uma intervenção.

A Arte-Terapia para nós, portanto, é de grande eficácia no sentido de que pode ajudar no desenvolvimento infantil no tocante a aprendizagem e nas relações com os outros e consigo mesmo. Desta troca, surgem novas posturas e novos indivíduos. Nesta perspectiva também, ainda que a representação da fala ou do gestual estejam empobrecidos ou ausentes, os recursos artísticos-terapêuticos propiciam ao indivíduo encontrar caminhos para expressar-se diferenciando-se do coletivo e reencontrando-se em si.

As intervenções as quais nos reportamos, portanto, nos fazem pensar em como iniciar uma tarefa - o primeiro passo, como fornecer elementos para que o indivíduo se organize etc. disso tudo, pensamos nas interferências no sentido que possam favorecer o processo criativo de cada um envolvido.

Com relação às oficinas propostas, creio que algumas delas devam ser retomadas, como por exemplo a criação do jardim, incluindo o relaxamento conduzido pela história falada, que leva até um jardim, ao invés da história ouvida no CD. Talvez, possa revelar maior devolutiva quanto à criação dos mesmos. Outro ponto relevante, é o material disponibilizado. Percebo que quando bem disposto e de fácil acesso, favorece bastante ao indivíduo a escolha, o manuseio e a partilha. Não depende portanto de um adulto para pegar para ele, não depende pedir permissão para o uso, não depende preocupar-se se pode ou não usar ou se tem usar isso ou aquilo. Ajudamos aqui na decisão do sozinho - na autonomia - importante a todos nós em diferentes situações da vida e que em última instância pode ser transposto às atividades cotidianas.

Com relação a teatralização do grupo, o seu empobrecimento notório de gestual e falas, merecem cuidados especiais quanto a futuros trabalhos em oficinas de criatividade. Penso que talvez, um repertório maior de histórias escolhidas pelo grupo devam, evocar maior empenho e envolvimento ou ainda que a leitura de histórias ou contos de fadas atrelada ao assistir de produções comerciais que prezem pela qualidade, colaborem para o crescimento do grupo neste sentido.

Outro ponto ao qual detivemo-nos em preocupação, é o da interação social no grupo. Alguns indivíduos necessitam de maior auxílio para o ajustar-se dentro dos limites necessários a convivência social. Assim, as intervenções além das dos recursos expressivos acontecem com a ajuda de um profissional qualificado. (psicológico). Neste particular, pudemos fazer uma interferência junto aos pais para que tomada ciência da problemática que no envolvia, pudéssemos soluciona-las sem prejuízos afetivos maiores. (vide A4).

Além das intervenções necessárias ao grupo, creio que um trabalho junto à família seja necessário. Podem descobrir como ajudar nesse processo de individuação, os seus filhos. Podem ainda fazê-los crescer rumo ao seu próprio processo de construção e elaboração de mundo, ressignificando-o numa perspectiva onde se possa descobrir seu lugar e suas potencialidades.

É verdade, porém, que para poder exerce seu potencial criador, agir criativamente em sua vida, seria preciso aos homens integrar-se enquanto pessoas, desenvolver-se e alcançar algum nível de maturidade e de individuação. Seria preciso aos homens encontrar condições de vida e de trabalho que proporcionassem os meios de realização de suas potencialidades, onde o seu fazer representasse uma fonte de conscientização interior a partir do qual eles se renovariam espiritualmente. (OSTROWER, 1977, p.134)

Desta forma, cremos que as oficinas podem ser mais que um espaço destinado ao realizar ou expressar-se simplesmente - revelam um espaço onde os sonhos adquirem formas, onde o 
não falar emerge através de riscos e cores, onde o gestual empobrecido pode ganhar forças na capa do herói.

\section{Conclusão}

A criatividade como agora a entendemos - algo que pode ser construído - nos possibilita pensar e retomar alguns aspectos preponderantes no fazer das oficinas de criatividade no tocante aos objetivos a que nos dispusemos investigar no que diz respeito à inclusão de alunos.

Assim sendo, temos claramente definido, que existe a necessidade de interferências de se trabalhar com uma gama de histórias diferenciadas que contribua ao sujeito maiores facilidades de compreender-se no caminho que tem que trilhar rumo a sua individuação, ordenação interior e harmonização - necessárias à expansão de suas potencialidades onde o foco central deva ser sempre o indivíduo que constrói seu próprio caminhar.

Desta forma, os recursos artísticos expressivos, oferecidos pela Arte Terapia, suscitam no indivíduo a sensibilidade necessária para o criar, dispensando e/ou reformulando a premissa de não se ater a repetição de modelos coisificando-se - ao contrário - os recurso propostos, abremse em oportunidades para o desvelar, caracterizando assim uma tomada de direção frente a unicidade, distinguindo-o do padrão coletivo. Neste pensar, creio que aos diversos indivíduos foi oferecida a possibilidade para além da criação artístico-expressiva.

Preocupamo-nos em representar conflitos existentes e discuti-los e ainda nos propusemos a sonhar e concretizar sonhos. Embora os sujeitos deste estudo sejam alunos com necessidades educativas especiais e possuam déficit intelectual, revelaram-se capazes em serem agentes de seus próprios processos de criação. Contrariamente ao que pensam alguns - o inconsciente como "um nada", para Jung, é ele - o inconsciente - o responsável em fazer emergir para nível consciente, os materiais necessários a cada indivíduo, e, a seu tempo (revelando-nos que cada um constrói a seu tempo o seu caminho) as nuances do processo de transformação.

Esse distanciamento do coletivo permite-nos pensar que indivíduos com necessidades educativas especiais são capazes de dar forma e representatividade de seu mundo interior. Ainda que tudo pareça caótico e desordenado e não sacralizado - enquanto espaço a ser preenchido e vivido - a Arte Terapia, através das técnicas em recursos expressivos permite-nos auxiliar os diversos indivíduos envolvidos no processo de criação a compreender-se e se fazer compreender, enriquecendo-nos.

Das imagens transformadas em objetos, pudemos ressignificar alguns pontos estruturando-os de tal forma que houvesse a necessária adequação - que cremos imprescindível para o harmonizar-se.

Das riquezas de tudo o que pode frutificar em oficinas de criatividade, pensamos sempre na necessidade que acompanha o homem desde tempos remotos em deixar sua marca - para tanto, diferenciar-se através do ato de criar, segundo padrões inventivos próprios, construindo um estilo único, denotando suas impressões do mundo e como o concebe numa posição dialética de construir construindo-se.

Como seres únicos a serviço de seus próprios avanços, entendemos, desta forma, que cada indivíduo reagiu de maneira diferente a um mesmo estímulo. Caracterizou-se, portanto, que alguns puderam avançar mais que outros frente a construção de seu processo criativo, enquanto outros, parecem necessitar de apoio maior para interar-se das propostas e delas tirar o máximo de proveito dinamizando seu potencial criador. Para àqueles que sofrem desta pseudo apatia quanto 
ao seu fazer criativo, preocupamo-nos em criar espaços outros que possam desencadear a busca pelo "eu", reafirmando-se em seu caminho particular, definido desta forma a perda da pluralidade tão comum ainda em alguns indivíduos do grupo.

Não obstante, esta pluralidade, enfocada de maneira diferenciada, norteia-nos para os aspectos importantes frente a diversidade existente nos mais diversos grupos sociais. Justamente por ela (diversidade) é que procuramos nos respeitar e respeitar aos outros e é também por ela, que sofremos todas as ressonâncias afetivas e culturais firmando em nós padrões comportamentais que nem sempre conseguem refletir aquilo que somos.

Embora não possamos antecipar a natureza da psique, conseguimos desenvolver a capacidade de desenvolver-nos a tal ponto que seja possível antecipar ações e pensamentos que ao menos nos assegurem maior conforto quanto às inquietações afetivas e sociais.

Criar, portanto, é transformar e desta transformação resultam novos indivíduos e novas expectativas garantindo que teremos infindáveis encontros interiores e ainda, que este processo jamais se extingue - ao contrário, adquire novas formas, ampliando-se.

É Ostrower (1977, p.130) quem tão bem explicita:

Formulamos aqui a idéia de que a criatividade se realiza em conjunto com a realização da personalidade de um ser: da maturação como processo essencial para a criação. Colocamos tanto as premissas como também os critérios de criação em uma possível maturidade do homem. Com sua maturidade o ser humano criará espontaneamente, exercerá a criatividade como função global e expressiva da vida, e como medida sua gratificação.

Para que processos como este explicitado venha nos afetar a todos, necessário se faz à criação de espaços para a criação, bem como o uso de recursos artísticos expressivos que respaldem o indivíduo, autor de sua obra, na formulação não só de caminhos disponibilizados para o caminhar e construir de seu processo, mas garantam que em momento algum não houve espaço por onde toda vazão criativa pudesse adquirir formas, conter cores, cheiros ou sabores.

Pensando em caminhos e rumos diversos, estamos longe de findar um assunto como o que abordamos neste trabalho: a criatividade e o processo de criação com alunos com déficit intelectual. Porém, estejamos certos de que sempre estamos procurando um "caminho" de desbravamento, um caminho que nos conduza a outros mundos, e que seja mágico nos fazendo reencontrarmos em nós.

O pequeno texto que se segue, criado pelo autor deste trabalho sugere além de uma condição intimista de busca, remetermos a novas pesquisas que colaborem para a ampliação do conhecimento em si, ampliando-nos em nossa busca do fazer e realizar objetivos.

Joga-te deste precipício

Acima

Abaixo e além

Sobrevoa o vôo

Flutua em asas outras

Morre d'outros amores

Saboreias liberdade 
Sons de saudade

Ouças por fim

O ruir de todo sonho triste

De todo dissabor que insiste

De toda morte em riste!

Esperas um pouco mais

Não finjas - já tens paz!

Ande então

Noutra direção.

\title{
Referências Bibliográficas
}

BRASIL. Ministério da Educação. Secretaria de Educação Fundamental. Secretaria de Educação Especial. Parâmetros Curriculares Nacionais: adaptações curriculares/ Estratégias para educação de alunos com necessidades educacionais especiais. Brasília: MEC/SEF, 1999.

BELINKY, Tatiana. Diversidade. São Paulo: Quinteto Editorial, 1999

BUENO, Silveira. Minidicionário da Língua Portuguesa. São Paulo: FTD, 1996.

BYINGTON, Carlos. Desenvolvimento e personalidade: símbolos e arquétipos. São Paulo: Ática, 1987. (Série Princípios)

ELIADE, Mircea. O Sagrado e o Profano: a essência das religiões. São Paulo: Martins Fontes, 2001.

ESSERS, Volkmar. Matisse. Alemanha: Taschen, 2001.

JUNG, Carl G. Os arquétipos e o inconsciente coletivo. Petrópolis: Vozes, 2000.

OSTROWER, Fayga. Criatividade e processos de criação. Rio de Janeiro: Imago, 1977.

PAÏN, Sara; JARREAU, Gladys. Teoria e técnica da arte terapia: a compreensão do sujeito. Porto Alegre: Artmed, 2001.

ROCHA, Ruth; TATIT, Paulo; PERES, Sandra. Mil Pássaros. [S.1]: MCD, 1999. 1CD

WALTER, Ingo F. Van Gogh. Alemanha: Taschen, 2001.

\begin{abstract}
Inclusion has been both a recurrent topic and a concern for educators. It is understood that Art may play a significant role since it can facilitate the development of the students. Thus in this paper I deal with the creativity issue in students with intellectual deficits as a productive alternative through the Art Therapy approach. The analysis of the individuation process and of the Jungian concepts that allow the use of art-therapeutic resources in favor of the understanding of the subject are consequences of this new approach. I touch upon the techniques and theoretical fundaments that are inherent to them and that consisted of the basis for the employed activities, that is, painting, collage, dramatizations and dolls which were used as theoretical basis for the elaboration of the practical work. The analysis of the collected data, in particular the interpretation of the creative process, refer to the data that is presented in three steps: the progress made by the group as the sequence of activities was applied and the creative
\end{abstract}


process that was acquired, the individual progress obtained with the application as far as social interaction is concerned, autonomy and organization and analytical interventions of the sequence of activities in favor of the creative efficiency. I highlight the achievements that were recognized in the creative process of the subject-students activated by the work that was proposed, with emphasis on the successful interventions and significant reflections on the work that was planned and applied.

Keywords: teaching, inclusion, art, creativity. 